\title{
Article
}

\section{Interpretation Catalysts and Executive Branch Legal Decisionmaking}

\author{
Rebecca Ingber $\uparrow$
}

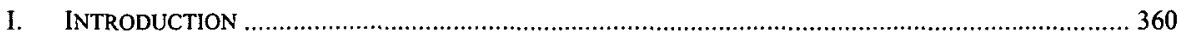

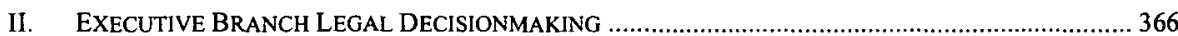

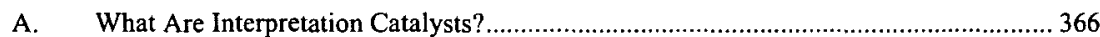

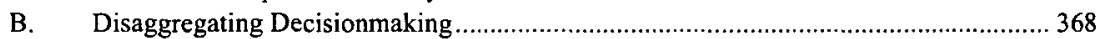

1. Interpretation Catalysts Empower Different Executive Actors .........................368

2. Interpretation Catalysts Trigger Different Mechanisms for Decisionmaking .... 372

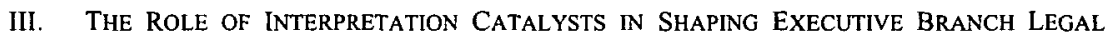

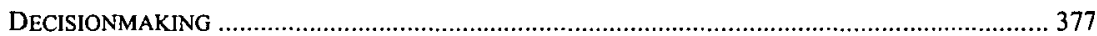

A. The Defensive Litigation Catalyst .................................................................... 378

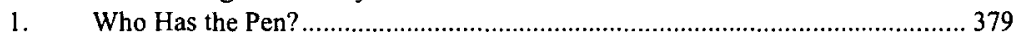

2. Mechanisms for Coordination and Decision................................................. 381

3. Contextual Pressures and Utility of the Litigation Catalyst.................................384

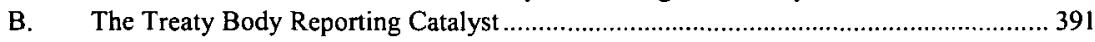

1. Who Has the Pen? ......................................................................................... 392

2. Mechanisms for Coordination and Decision..................................................... 393

3. Contextual Pressures and Utility of the Treaty Body Reporting Catalyst ...........395

C. Speechmaking as Interpretation Catalyst .................................................................. 397

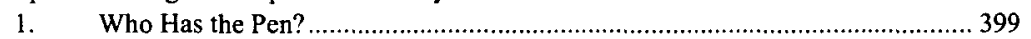

2. Mechanisms for Coordination and Decision..............................................401

3. Contextual Pressures and Utility of the Speechmaking Catalyst......................401

IV. COMPaRing Catalysts, a CASE StUdy: THE 2005-2006 Report to THE COMMITTEE

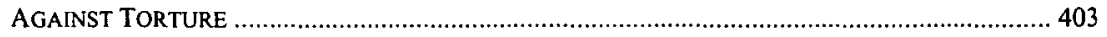

V. IMPLICATIONS OF THE INTERPRETATION CATALYST PHENOMENON

$\dagger \quad$ Associate Research Scholar, Columbia Law School; 2011-2012 Council on Foreign Relations International Affairs Fellow and Hertog National Security Law Fellow, Columbia Law School. I served from 2006 to 2012 in the Office of the Legal Adviser at the U.S. Department of State. The views expressed here are my own and do not necessarily reflect the views of the U.S. Department of State or the U.S. Government. In addition to works cited, I have relied on information and wisdom received from many current and former officials from throughout the U.S. government who were extraordinarily helpful and generous with their time. In particular I am indebted to Evelyn Aswad, John Bellinger, Sarah Cleveland, Lori Damrosch, Lara Flint, Joseph Guerra, Avril Haines, Robert Harris, Karen Hecker, Steven Hill, Sandra Hodgkinson, Richard Jackson, Frank Jimenez, Martin Lederman, Robert Loeb, Julie Martin, Thomas Monheim, Vijay Padmanabhan, and Sabeena Rajpal. I would also like to thank Kate Andrias, William Banks, Jennifer Daskal, Ashley Deeks, Harold Koh, Peter Margulies, Daniel Meltzer, Anton Metlitsky, Gillian Metzger, Trevor Morrison, Julian Mortenson, Alexandra Perina, David Pozen, Daphna Renan, Sharmila Sohoni, Matthew Waxman, Benjamin Wittes, and Saul Zipkin as well as members of the Columbia Law School Fellows Workshop and the 2012 meeting of the American Society of International Law's Interest Group on International Law in Domestic Courts, held at Duke Law School, for helpful comments on drafts. 
A. Implications for Scholarship.

B. Implications for Advocates

C. Implications for the Courts ...

D. Implications for Executive Branch Actors.

\section{INTRODUCTION}

Consider the following scenarios in which the United States government must establish a position on its legal authority to detain in a nontraditional conflict such as that with al Qaeda. First, envision exigent combat circumstances: U.S. military operatives find themselves confronting individuals connected to al Qaeda whom they would like to capture and detain, and must determine the scope of their legal authority to do so. Now imagine this question arises in the context of a major report the United States is due to provide to the monitoring committee for a human rights treaty, explaining its understanding of its obligations under and compliance with the provisions of that treaty. Finally, consider how this interpretation might play out if U.S. officials were first asked to state the government's legal authority for detention in the context of litigation brought by individuals who allege that the government has unlawfully detained them. Might the executive's position on its legal authority, or even its willingness to stake out a position, differ depending on which of these contexts first triggers the question for legal decisionmakers? If so, why?

Each of these scenarios presents an example of what this Article terms an "interpretation catalyst"-a distinct triggering event compelling the U.S. government to consider, determine, and potentially assert an interpretation of its obligations and authority under domestic or international law. Interpretation catalysts exist in countless forms and play a significant and at times decisive role in shaping the executive's legal and policy ${ }^{1}$ decisionmaking processes and ultimate decisions. Interpretation catalysts can drive the executive branch to crystallize a legal view on a matter that is entirely novel; can bring a formerly identified but dormant issue into urgent focus; and can transfer an issue from one decisionmaking forum to another. ${ }^{2}$ The resulting processes triggered by these catalysts then have dramatic-and often predictable-effects on the executive's ultimate position. That position and the catalyst that influences it are all the more important because of the stickiness of executive decisions, and legal positions in particular, once taken. This Article explores the critical role played by interpretation catalysts in influencing the executive's ultimate substantive legal decisions, including by determining a particular question's

1. Determining the lawful parameters of executive action is only one piece of the policy decisionmaking scheme. Yet because of the complexity and interconnectedness of law and policy in this arena, as well as the necessity for guidance on questions of legal policy in addition to those of pure legal interpretation, executive branch lawyers play a critical role and their decisions and advice heavily inform the scope of options available.

2. See infra Part II. 
point of entry within the government, framing the task, shaping the interpretive process, establishing the relative influence of the relevant actors, and informing the contextual pressures and interests that may bear on the decision.

The executive does not bind itself easily to new legal constraints, nor does it ordinarily do so in the absence of a forceful catalyst. ${ }^{3}$ This is all the more true in matters of national security. Nevertheless, due to broad judicial deference and sufficient congressional acquiescence (with some notable exceptions), executive branch legal positions are often the critical (and at times the only) relevant substantive statements of law in this area. ${ }^{4}$ The executive's interpretation of its national security authority is therefore extremely significant and can often serve not only as one step in an inter-branch interpretive dance, but as lawmaking itself.

How this legal decisionmaking occurs remains fairly opaque, even despite great speculation in recent years. Vigorous debate rages over executive authority and its limits: why the executive arrives at particular understandings of its legal constraints, ${ }^{5}$ why presidential administrations break with or continue the legal positions and policies of their predecessors, ${ }^{6}$ whether sufficient structural constraints-including internal executive offices-exist to rein in otherwise unbridled presidential power, ${ }^{7}$ and the extent to which the executive is truly constrained by law at all. ${ }^{8}$ Nevertheless the process of executive legal

3. See infra Section II.A.

4. See infra text accompanying notes $89-90$.

5. See infra Section V.A.

6. See, e.g., JACK GoldSMith, Power AND CONSTRAINT: THE ACCOUNTABLE PRESIDENCY AFTER 9/11, at 25-28 (2012) [hereinafter GOLDSMITH, POWER AND CONSTRAINT] (discussing structural limitations on the Obama administration's ability to change national security positions once in office, though focusing primarily on what Goldsmith views as rational reasons for consistency).

7. See, e.g., Neal Katyal, Internal Separation of Powers: Checking Today's Most Dangerous Branch from Within, 115 YALE L.J. 2314, 2316 (2006); Gillian Metzger, The Interdependent Relationship Between Internal and External Separation of Powers, 59 EMORY L.J. 423 (2009). There has been a vibrant debate in recent years concerning the role of the Department of Justice Office of Legal Counsel (OLC) and whether it serves to constrain and defend-or merely rubber-stampPresidential authority. This debate stems in part from controversies involving the Bush-era OLC, which critics accused of over-politicization and of providing rubber-stamp legal justification for extralegal activity and abuse; thus, much scholarship has focused on either lambasting or resurrecting the office's role in executive branch legal interpretation. See, e.g., BRUCE ACKERMAN, THE DECLINE AND FALL of THE AMERICAN REPUBLIC (2010) [hereinafter ACKERMAN, REPUBLIC] (proposing, inter alia, the creation of an independent "Supreme Executive Tribunal" within the executive branch with binding authority to answer legal questions); Bruce Ackerman, Lost Inside the Beltway, 124 HARV. L. REV. F. 13 (2011), http://www.harvardlawreview.org/media/pdf/voll24forum_ackerman.pdf; Katyal, supra, at 2337 (arguing that the adjudicative function of OLC should be stripped away from its advisory function, and "transferred to a separate official, a Director of Adjudication, who would resolve inter-agency disputes"); Trevor W. Morrison, Constitutional Alarmism, 124 HARV. L. REV. 1688 (2011) [hereinafter Morrison, Alarmism] (challenging Ackerman's critique of the OLC and his proposed reforms); Trevor W. Morrison, Libya, "Hostilities," the Office of Legal Counsel, and the Process of Executive Branch Legal Inteprretation, 124 HARV. L. REV. F. 62, 63 (2011) [hereinafter Morrison, Libya], http://www.harvardlawreview.org/media/pdf/vol124_forum_morrison.pdf; Bruce Ackerman, Legal Acrobatics, Illegal War, N.Y. TIMES, June 21, 2011, at A27 [hereinafter Ackerman, Legal Acrobatics].

8. See, e.g., ERIC A. POSNER \& ADRIAN VERMEULE, THE EXECUTIVE UNBOUND: AFTER THE Madisonian RePUBLIC (2010); Richard H. Pildes, Law and the President, 125 HARV. L. REV. 1381 (2012). Moreover, international law theorists have explored how activities of diverse individuals within and outside government inform international law compliance. See, e.g., Anne-Marie Slaughter Burley, 
decisionmaking itself remains relatively mysterious. Yet process-and the catalysts for decisionmaking that help shape that process-has a significant impact on the executive's view of its own authority. Consideration of the interplay between these catalysts and the enormous diversity of actors and processes within the executive that overlap, collide and collaborate to formulate executive decisions provides valuable texture to these dialogues on executive authority. ${ }^{9}$

Current scholarship on executive lawyering tends to focus predominantly on select offices-in particular, the Office of the Solicitor General ${ }^{10}$ and the Office of Legal Counsel in the Department of Justice, ${ }^{11}$ and to a lesser extent individual agency general counsels ${ }^{12}$-as well as on the bilateral relationship between each of these offices and the White House. But there has been very little exploration of the broader interaction among executive branch legal offices and the role of these dynamics in decisionmaking. A handful of scholars have considered the broader spectrum of legal actors throughout the executive; and yet-despite the acknowledgment and even reliance by much administrative law scholarship on the existence of multiple deciders within the executive branch $^{13}$ - there is a tendency within the emerging literature on interagency legal decisionmaking to employ a President-focused, unitarydecider view of this process. ${ }^{14}$ Under this view the proliferation of legal advice from different actors throughout the executive simply provides greater options for the President among which to choose. ${ }^{15}$ The assumption underlying this

International Law and International Relations Theory: A Dual Agenda, 87 AM. J. INT'L L. 205, 207 (1993); Harold Hongju Koh, Transnational Legal Process, 75 NEB. L. REV. 181, 206 (1996).

9. See infra Sections II.B, V.A.

10. See, e.g., Rebecca Mae Salokar, Politics, Law, and the Office of the Solicitor General, in

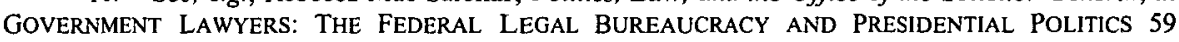
(Cornell W. Clayton ed., 1995).

11. See ACKERMAN, REPUBliC, supra note 7; Ackerman, Legal Acrobatics, supra note 7; Katyal, Internal Separation of Powers, supra note 7; Morrison, Alarmism, supra note 7; Morrison, Libya, supra note 7.

12. For a rare look at the role of agency general counsel offices, see Michael Herz, The Attorney Particular: Governmental Role of the Agency General Counsel, in GOVERNMENT LAWYERS, supra note 10, at 143. For an unprecedented historical account of the State Department Office of the Legal Adviser, see MICHAEL SCHARF \& PAUL WILlIAMS, SHAPING FOREIGN POLICY IN TIMES OF CRISIS (2010).

13. See infra notes $37-38$.

14. For rare exceptions, see ABRAM ChAYES, THE CUBAN MISSILE CRISIS: INTERNATIONAL CRISES AND THE ROLE OF LAW 13-24 (1974), which describes the reality of interagency legal and policy decisionmaking during the Cuban missile crisis; GOLDSMITH, POWER AND CONSTRAINT, supra note 6; and JACK GOLDSMITH, THE TERROR PRESIDENCY: LAW AND JUDGMENT INSIDE THE BUSH ADMINISTRATION 167 (2007) [hereinafter GOLDSMITH, THE TERROR PRESIDENCY], which discusses the virtues of coordinated interagency process in legal decisionmaking.

15. See, e.g., Neomi Rao, Public Choice and International Law Compliance: The Executive Branch Is a They Not an It, 96 MINN. L. REV. 194 (2011) (examining the diversity of potential legal advice within the executive branch and concluding that it provides the President with greater options and thus keeps international law somewhat flexible); see also Ackerman, Legal Acrobatics, supra note 7 (criticizing the Obama Administration for, in his view, creating a precedent in which a President could "organize a supportive "coalition of the willing' made up of the administration's top lawyers," in order to get support from "one or two [which] would be enough to push ahead and claim that the law was on the president's side"). 
approach is that the President has an outcome he or she prefers, and thus relies on the existence of multiple advisors in order to increase the likelihood that at least one will be willing to provide legal justification for that outcome. ${ }^{16}$

This Article explores interagency legal decisionmaking from a different perspective. Rather than viewing executive legal interpretation from the President down, I examine the diverse kinds of catalysts, external and internal, that trigger decisionmaking from the bottom up and horizontally, and how these catalysts inform the processes, players, and ultimate decisions that may either never reach the President, or reach him in a packaged, processed form that will heavily inform his decisionmaking. ${ }^{17}$ The President-as-unitary-decider model described above may account for some limited, rare circumstances, but it does not represent the ordinary process in which legal positions are factored intoand may weed out-policy options at lower levels before reaching the President's desk, even when he is the ultimate decider on the broader package. ${ }^{18}$ It certainly does not account for the vast majority of decisions that do not reach the Oval Office, and thus places an outsized emphasis on the President's role in coordinating disagreement between agencies over particular matters of legal interpretation.

Almost all legal decisionmaking within the executive is far more complex than the model of one decider choosing among all possible options. ${ }^{19}$ The exploration of executive branch decisionmaking presented here is influenced in part by scholarship in organizational theory and behavioral economics observing how institutional design and process, framing and sequencing of decisions, and individual actors themselves can and do have a significant impact on decisionmaking and ultimately on substance. ${ }^{20}$ Political and behavioral scientists have long explored the significant effects of framing and sequencing of choices on individuals' subsequent decisions. ${ }^{21}$ Scholars have

16. Ackerman, Legal Acrobatics, supra note 7.

17. See, e.g., Michael E. Levine \& Charles R. Plott, Agenda Influence and Its Implications, 63 VA. L. REV. 561 (1977).

18. Id,; see infra note 84 and accompanying text.

19. See, e.g., Morrison, Libya, supra note 7, at 67. In response to Ackerman's criticismbased on press reports regarding the President's legal decisionmaking process regarding actions in Libya-that the President had simply chosen the legal advice that favored his preferred outcome, Morrison states: "From my own time in public service I know all too well that the reality of government decisionmaking is often much more complicated than appears in the press." Id.

20. This Article follows in the path broken by Graham Allison in Essence of Decision. Graham Allison, EsSENCE of Decision: EXPLAINING THE CuBAN Missile CRISIS (1971). Allison incorporated organizational and politics models of bureaucratic decisionmaking to illustrate the criticality of process and politics to decisionmaking. Scholars of the Presidency have continued to explore these influences since and have built on this work. See, e.g., ROGER B. PORTER, PRESIDENTIAL DECISION MAKING: THE ECONOMIC POLICY BOARD (1980) (explaining the structures presidents employ for managing the executive bureaucracy and their own effectiveness); JAMES $Q$. WILSON, BUREAUCRACY: WHAT GOVERNMENT AGENCIES DO AND WHY THEY DO IT (1989); see also infra notes 37-38 (discussing administrative law scholarship addressing institutional design and executive decisionmaking).

21. See, e.g., Eric J. Johnson et al,, Framing, Probability Distortions, and Insurance Decisions, in CHOICES, VALUES, AND FRAMES 224, 238 (Daniel Kahneman \& Amos Tversky eds., 2000) (arguing that consumers' insurance decisions vary according to framing of premiums and benefits); Peter Rutledge, Decisional Sequencing, 62 ALA. L. REV. 1 (2010) (finding that decisional sequencing 
shown, for example, that strategic casting and sequencing of questions on a club's meeting agenda can alter the outcome of voting by a group of individuals inclined toward a different position, ${ }^{22}$ and others have proposed that simply rearranging the location of food options in a school cafeteria would dramatically alter children's consumption of French fries and carrot sticks. ${ }^{23}$ I suggest that these effects can be compounded dramatically in an organizational context. In organizational-and here executive branch-decisionmaking, the individuals involved and their functions may actually change, and the entire decisionmaking structure may organize differently according to the task at hand. In other words, to use the club meeting example, imagine the compounded effect of these behavioral influences if the actual voting group might transform into a different set of individuals - with a different chair of the meeting and some voting members replaced by others, with different priorities and biases-depending on the nature of the meeting agenda. Such is the nature of much executive branch legal decisionmaking. Thus, while behavioral effects continue to operate on individual actions in executive lawyering as in any decisionmaking, they also play out on a colossal scale when the actor is not simply one individual but rather a massive, multifaceted organization whose decisionmaking gears shift into entirely different places and whose individual players reshuffle depending on the framing of the initial triggering event.

While the focus of this Article is the role of interpretation catalysts in shaping international law and national security legal interpretation within the executive branch, this phenomenon is by no means limited to government action, national security, or legal interpretation. The "interpretation catalyst" phenomenon might be applied to decisionmaking of any kind within any sufficiently complex bureaucracy. I focus here on executive branch legal interpretation in these areas because of the importance of the legal questions at stake, the stickiness of these decisions once taken and thus their long-lasting effects on executive positions, and the outsized role the executive bureaucracy plays in determining the law that binds it. Moreover, matters of national security and international law lend themselves well to this study, as a broad range of decisionmakers operate throughout the executive on matters of overlapping jurisdiction and interest, and legal and policy questions often have

\footnotetext{
can affect judicial decisions); William Samuelson \& Richard Zeckhauser, Status Quo Bias in Decisionmaking, 1 J. RISK \& UNCERTAINTY 7, 8 (1988) (finding that decision makers exhibit a significant bias toward the status quo); Daniel M. Isaacs, Note, Baseline Framing in Sentencing, 121 YALE L.J. 426, 449 (2011) (finding that judges are affected by the framing of legal questions). For a discussion of these effects on international law, in particular on states' decisions regarding treaty reservations, see Jean Galbraith, Treaty Options: Towards a Behavioral Understanding of Treaty Design, 53 VA. J. INT'L. L. 309 (2013). See also UndERSTANDING SOCIAL Action, Promoting HuMAN RIGHTS (Ryan Goodman et al. eds., 2012) (proposing application of tools from social sciences to human rights promotion.)

22. Levine \& Plott, supra note 17 (finding that casting and sequencing of a meeting agenda can determine the outcome of voting).

23. Richard H. Thaler \& Cass R. Sunstein, Nudge: improving Decisions about HEALTH, WEALTH, AND HAPPINESS 1 (2008) (terming this use of "nudges" to encourage decisionmaking, "choice architecture").
} 
a range of reasonable answers. ${ }^{24}$ Because of these characteristics, the structure and process for decisionmaking in this area can have an outsized effect on the resulting decision.

This Article advances two primary arguments: First, I argue that how a legal question arises for the executive shapes the process of decisionmaking and thus the substantive outcome, which typically becomes the executive's entrenched position going forward. Second, I contend that within executive branch legal decisionmaking, some processes-and thus the interpretation catalysts that trigger them-are better suited for certain kinds of decisionmaking than are others, and that the results are often predictable. These two arguments have wide-ranging implications.

This Article proceeds as follows. Part II grounds the discussion in a background understanding of the moving gears and levers of executive branch lawyering in the fields of national security and international law. This Part explains how opportunities arise for legal decisionmaking within the executive, and the stickiness of executive decisions once made, and introduces the relationship between interpretation catalysts and the executive's ultimate legal positions. It then examines the enormous breadth of legal decisionmakers and potential mechanisms for coordination of decisionmaking throughout the executive branch. The multiplicity of players and processes for decisionmaking in this area increases the potential influence of distinct interpretation catalysts in shaping how decisionmaking occurs, and thus the resulting substantive outcome.

Part III then demonstrates the phenomenon and effects of interpretation catalysts through the detailed exploration of three unique triggers for executive branch legal decisionmaking: defensive litigation, treaty-body reporting, and speechmaking. It explores the role of each catalyst in shaping the process, players, and contextual pressures of legal decisionmaking, and thus its distinctive influence on the ultimate substantive position taken by the executive. In revealing the diverse and often predictable effects of distinct interpretation catalysts on executive decisionmaking, Part III also explores the relative influence of each catalyst and its predisposition toward different types of decisions.

A comparison of the effects of distinct interpretation catalysts on decisionmaking-and the propensity of each toward different results-demonstrates that different catalysts are more or less suited to different kinds of decisions. Factors such as the level of coordination, the time permitted for reflection, or the status of the officials involved exert a significant influence on the shape of the resulting decision-including whether it is likely to entrench or challenge the status quo- and are heavily influenced by the interpretation catalysts that trigger the decisionmaking process. Part IV illustrates this phenomenon through a case study involving the Bush Administration's 20052006 report to the monitoring committee of the Convention Against Torture.

24. See infra Section II.B. 
The interpretation catalyst phenomenon has wide-ranging implications for scholars, advocates, courts, and the executive itself. Part V surveys a selection of these implications. It addresses ongoing debates about executive power and constraint that would benefit from wrestling with the influence of interpretation catalysts on executive decisionmaking. This Part also explores the implications of interpretation catalysts for private advocates, who can maximize their efforts to challenge executive legal positions and policies by considering which pressure points are more or less likely to produce the outcomes that they support. Finally, it suggests a rethinking of the current state of judicial deference to executive positions in the area of national security and international law, in light of the inordinate influence of litigation itself on the process and results of executive decisionmaking.

\section{EXECUTIVE BRANCH LEGAL DECISIONMAKING}

Before exploring the operation and effects of specific interpretation catalysts on executive legal decisionmaking, some scene-setting is necessary. This Part therefore provides background on certain key components of national security legal decisionmaking within the executive-in particular the players involved, and the way they organize to arrive at decisions-in order to set the stage for a deeper exploration of the work of interpretation catalysts in Parts III and IV. This Part does not generally proffer conclusions about the nature of particular processes, how they differ substantively, or how they are likely to shape the resulting decisions. Instead, it provides a necessary backdrop to Part III, which turns to a more thorough investigation of distinct interpretation catalysts, the role they play in triggering decisionmaking players and mechanisms, the distinctive biases and proclivities of the resulting decisionmaking processes, and their effects on ultimate executive positions.

\section{A. What Are Interpretation Catalysts?}

Executive branch decisionmaking typically moves at a glacial pace. Significant shifts in the executive's positions are rare. Legal interpretations are particularly sticky; once made (especially when made publicly), they tend to become entrenched unless forcefully overturned. This is true for a host of reasons, including the deep-seated legal traditions that emphasize precedent and consistency as integral to the rule of law, ${ }^{25}$ as well as the effects of path dependence and status quo bias on subsequent decisionmaking, the enormous transaction costs of arriving at a decision in the first place, and the resistance of government bureaucracy to change. ${ }^{26}$

25. See, e.g., Trevor W. Morrison, Stare Decisis in the Office of Legal Counsel, 110 Colum. L. REv. 1448, 1494-95 (2010) (discussing the role of precedent and the values of "consistency and predictability in the law").

26. See, e.g., Oona A. Hathaway, Path Dependence in the Law: The Course and Pattern of Legal Change in a Common Law System, 86 lowA L. REV. 601, 605 (2001) ("[E]arly resolutions of legal issues can become locked-in and resistant to change."); Samuelson \& Zeckhauser, supra note 21 (discussing status quo bias). 
Nevertheless, windows for novel interpretation or position reversals do occur, and the resulting decisions are all the more important because of their likely entrenchment. ${ }^{27}$ Moreover, small-scale questions arise constantly that lead to mini-interpretations that over time can develop into significant decisions. Attorneys throughout the executive branch-whether employed in political or career positions; in agency general counsel offices, the Department of Justice, or the White House; as heads of offices or as line attorneysconfront numerous questions a day that require them to understand, interpret, and assert publically or internally the government's legal position on a particular issue. $^{28}$

Interpretation catalysts, as identified and defined by this Article, are the triggering events that impel the executive-or any institution-to consider, determine, and assert, whether publicly or not, a position on a matter of legal interpretation. Interpretation catalysts exist in many forms, ${ }^{29}$ three of which I wrestle with in Part III. Interpretation catalysts may be clear-cut distinct events --for example, a request for legal guidance by an executive official who desires to use force against a specific target. Or they can also include a complex array of triggers that together compel an executive position, such as a lawsuit challenging that executive action, in which executive officials must assert a broad legal position on a matter, some piece of which had previously been considered internally. ${ }^{30}$ Moreover, interpretation catalysts can involve external triggers - such as a treaty body requesting a report on a state's compliance; ${ }^{31}$ internal triggers - such as the above request for legal guidance by an executive official; or a mix of these-such as the internal decision by executive officials to explain the executive's position in a speech or other announcement, prompted by external calls for transparency. ${ }^{32}$

27. See, e.g., JoHn W. KINGdon, Agendas, Alternatives, And Public POliCies 203-04 (2d ed. 1995) (highlighting the importance of "policy windows" in effecting change); Hathaway, supra note 26, at 605 ("Opportunities for significant legal change in a common law system are brief and intermittent, occurring during critical junctures when new legal issues arise or higher courts or legislatures intercede.").

28. See, e.g., David J. Barron \& Elena Kagan, Chevron's Nondelegation Doctrine, 2001 SuP. CT. REV. 201, 202-03 (noting that many agency decisions stem from "relatively informal, 'non-rulelike,' or decentralized forms of administrative action," and "not from the central hierarchy of the agency but from branch offices or limited subject matter divisions"); David Fontana, Executive Branch Legalisms, 124 HARV. L. REV. F. 21, 42 (2012), http://www.harvardlawreview.org/media/pdf/forvol126_fontana.pdf (explaining the importance of the vast civil service legal bureaucracy, in which "[c]ivil service lawyers have the final word on executive branch law in a large number of situations").

29. Interpretation catalysts in matters of national security can be: (1) adjudication-driven (including both domestic and international litigation, as well as administrative processes); (2) futureaction or policy-driven (e.g., a proposal by government officials to use force to target an individual or object, or the establishment of administrative procedures for detainees); (3) event-driven (e.g., an upcoming conference, speech, or testimony before Congress); (4) soft law-driven (e.g., treaty body reporting processes and resolutions); and (5) hard law-driven (e.g., bilateral and multilateral treaty negotiations, U.N. Security Council Resolutions, and responses to legislation).

30. See infra Section III.A.

31. See infra Section III.B.

32. See infra Section III.C. 
Interpretation catalysts not only prompt new questions; they can also operate as action-forcing events for matters that are otherwise moving along cautiously or might otherwise have been left dormant. ${ }^{33}$ Moreover, matters under discussion in one process may, by virtue of a particularly forceful interpretation catalyst, shift suddenly into another. ${ }^{34}$ Litigation is an interpretation catalyst that-due to factors such as time pressure, external enforcement, and the potential for significant concrete consequences-tends to take precedence over other catalysts.

When interpretation catalysts arise, the unique nature of the particular trigger involved shapes the resultant legal decisionmaking process within the executive. ${ }^{35}$ Each interpretation catalyst starts the decisionmaking process from a distinct point within the bureaucracy and in a context tailored to that particular trigger. The initial catalyst affects not only the identity of the initial actor who responds to that trigger, but also the identity of the relevant government actors who participate in the resultant process, and their relative status, influence, and ultimate authority. It frames the task at hand-including whether a legal interpretation or policy decision is required-and it shapes the context and the pressures, biases, and interests in light of which the decisionmaking proceeds. All of these factors play a critical and potentially transformative role in shaping executive decisions; thus the influence of the distinct interpretation catalyst on the decisionmaking process grants it significant potential to influence the substance of the ultimate-likely enduring-executive position.

\section{B. Disaggregating Decisionmaking}

The importance of the entry point of a decision is due in large part to the existence of numerous relevant players-including legal players-within the executive who have distinct roles yet who overlap in their substantive interests, expertise, and spheres of influence, as well as a variety of mechanisms for coordinating decisionmaking. The decisionmaking mechanism, or process, employed and the identity and stature of the players involved can have a critical impact on the resulting decision, and are heavily informed by the nature of the initial interpretation catalyst.

\section{Interpretation Catalysts Empower Different Executive Actors}

One of the key effects interpretation catalysts have on executive legal interpretation is to influence the identity and authority of the relevant legal decisionmakers involved in a given issue. That different "deciders" exist

33. See infra text accompanying note 189.

34. See infra text accompanying notes 75-79.

35. See infra Part III. 
throughout the executive branch should not be a matter of controversy. ${ }^{36}$ In fact, there is an implicit assumption underlying much scholarship on the executive that there are varied potential governmental decisionmakers, that decisionmaking structures and individual authority can change, and that different processes could and do lead to elevation or subordination of different decisionmakers, ${ }^{37}$ and thus to different results. ${ }^{38}$ This is true even in the realm of legal interpretation, ${ }^{39}$ though the existence of multiple legal deciders may be somewhat more disquieting to some. Yet a vast network of lawyers exist throughout the executive who proffer legal guidance on a regular basis, who are at times called upon to declare those views publicly, who can hold the power to speak authoritatively for the U.S. government on matters of legal interpretation and policy and whose command over a matter can rise or fall depending on the operating organizational structure.

Much scholarship on executive branch decisionmaking-including both administrative law scholarship ${ }^{40}$ and literature on executive legal interpretation ${ }^{41}$ - at least implicitly recognizes that the President is not always the ultimate decider. This is an understatement. The President is almost never the decider on the vast majority of decisions that take place throughout the executive branch, and this is all the more true in matters of legal interpretation. $^{42}$ In fact, there are literally thousands of lawyers in general counsel offices in every agency who play an enormous role in the daily and long-term formulation of policy and legal interpretation, ${ }^{43}$ and decisions are made on a near constant basis by cabinet-level heads of agencies, by politically

36. AlLISON, supra note 20 , at 80 (explaining that the size of organizations "prevents any single central authority from making all important decisions," and that the important provision of "specialized attention to particular facets of problems" has the inherent result that "government leaders [cannot simply] cope with the problems themselves").

37. Much administrative law scholarship wrestles with the ideal allocation of authority among executive branch officials, thus presuming the existence of multiple deciders whose relative authority can shift as a consequence of structural or incentive changes, which in turn can lead to different substantive outcomes. See, e.g., Elena Kagan, Presidential Administration, 114 HARV. L. REV. 2245 (2001) (arguing for heightened Presidential involvement in agency decisionmaking so as to increase, inter alia, accountability in the resulting government actions); Neal Katyal, Internal Separation, supra note 7; Elizabeth Magill \& Adrian Vermeule, Allocating Power Within Agencies, 120 YALE L.J. 1032, 1059 (2011) (arguing, inter alia, that administrative law jurisprudence determines the relative influence of different officials within agencies).

38. See, e.g., Barron \& Kagan, supra note 28, at 234-35 (noting that "agencies are multifaceted organizations, made up of diverse actors with diverse attributes and orientations," and that as "hierarchically structured organizations," "different levels of actors respond to different constraints and incentives, thus making different decisions").

39. See, e.g., GOLDSMITH, POWER AND CONSTRAINT, supra note 6; GOLDSMITH, ThE TERROR PRESIDENCY, supra note 14.

40. See supra notes $37-38$.

41. While emerging scholarship on interagency legal dynamics tends to take a Presidentfocused view, much scholarship on individual legal offices within the executive contemplates that these offices take positions that either do not reach the President or may not align with his preferences. See supra notes 7, 12-15, and accompanying text.

42. See, e.g., infra Subsection I.B.2 (discussing the limited decisions that reach the President, the packaged form in which they do so, and the constraints on his ability to overrule legal decisions).

43. See e.g., Morrison, Alarmism, supra note 7, at 1733-34 n.176 (noting the incredible proliferation of attorneys in agency general counsel offices throughout the executive branch). 
appointed and Senate-confirmed general counsels, and by both political and career officials at lower levels throughout the government bureaucracy. ${ }^{44}$ These officials communicate and coordinate across agencies and components of their agencies at all levels of hierarchy, and thus even those decisions that involve significant interagency interaction may never reach the desks of high-level people within those very agencies, let alone the White House. Those that do have typically been so haggled over by agency officials-handled by White House staffers-and are so deeply embedded in the related policy action, that when they finally reach the President, the question is rarely "what is your best view of the law on this question," but rather a complex policy choice, often including the preferences and guidance of cabinet officials and staffers, with possible additional information including the legal risks associated with each. ${ }^{45}$ Of course, many of the decisions regarding legal risks and constraints made by lower level officials along the way will influence the parameters of the policies and options presented, thus playing a huge role in policy formation ex ante. ${ }^{46}$ The scenario can also work in reverse: if the President or White House staffers are interested in pursuing a policy or action, they may request guidance on their legally available options, ${ }^{47}$ thus acting as an interpretation catalyst from the top down.

Numerous executive branch offices, including the offices of general counsel and other components of all relevant national security entities such as Defense, State, Justice, and the Intelligence Community, as well as counsel and other staff at the White House and National Security Council, play critical roles in the national security legal architecture. ${ }^{48}$ DOJ alone contains several intersecting and sometimes competing offices that play key roles in national security law and policy, such as the National Security Division, the Office of the Solicitor General, the Office of Legal Counsel, and the major trial and appellate litigation divisions that represent and defend the executive's positions

44. See, e.g., Magill \& Vermeule, supra note 37, at 1038 (noting an allocation of "power within an agency both horizontally (to different types of decisionmakers at roughly the same level at the agency) and vertically (to decisionmakers at varying levels within the agency hierarchy)"). I also use "horizontal" to include the disaggregation of decisionmaking throughout the interagency in addition to within a given agency.

45. See, e.g., JAMES BAKER, IN THE COMMON DEFENSE 105-21 (2007) (discussing how NSCled meetings and staff serve to frame matters for Presidential decision); Fontana, supra note 28 (noting that legal issues typically reach political lawyers only "after civil service lawyers have already framed the issue in important ways, and it is difficult to diverge from these civil service framings"); Levine \& Plott, supra note 17.

46. See, e.g., GRAHAM Allison \& PETER SZANTON, REMAKING FOREIGN POLICY 18 (1977) (explaining the limited alternatives presented to the President by analogy to choosing an entree from the menu at a Chinese restaurant: the President has ultimate decision making authority, but is constrained by the options presented by his advisers and the rest of the bureaucracy, so no matter what entrée he chooses, he's going to be eating Chinese food, not coq au vin); CHAYES, supra note 14.

47. I am grateful for this insight to Trevor Morrison, who provided comments on this Article.

48. See, e.g., Rao, supra note 15 (examining the roles and distinct leanings of the State Department Office of the Legal Adviser, The Defense Department Office of General Counsel, DOJ Office of Legal Counsel, and the National Security Legal Adviser). 
and programs in the lower courts. ${ }^{49}$ Each of these offices engages in legal interpretation-and decisionmaking generally-from a distinct organizational perspective. ${ }^{50}$ Putting aside the possibility of bad actors, all understand their task to be ensuring proper legal guidance to their policy clients and to the President. Yet this task and the resulting legal guidance can be highly influenced by the role of the particular office and the policy goals of its client. ${ }^{51}$ This role can vary dramatically across offices and according to the task at hand. ${ }^{52}$ For example, advice may differ dramatically between an office tasked with protecting the executive from litigation risk before action is taken, and one that must defend aggressive executive action ex post. ${ }^{53}$ Particularly when it comes to the application of international and domestic law to modern armed conflict and security threats, there is often a range of plausible legal interpretations. An agency or official's position on a legal question-even its best reading of the law-will understandably vary somewhat according to its distinct purpose and focus, among other factors. ${ }^{54}$ And since national security and international law matters by their nature often involve issues of heavily overlapping jurisdiction, the tension of competing views among executive branch offices and officials is often acutely significant.

At least with respect to matters on which there is a range of plausible views, it should be clear that the relative influence-both as a matter of structure and of personality-of a particular individual or office within the executive branch can matter a great deal to the executive's ultimate substantive position. Thus the allocation of decisionmaking authority, or even persuasive power, ${ }^{55}$ to different components or individuals within the executive branch can have a significant effect on the substantive outcome. ${ }^{56}$

49. These include Federal Programs and the Torts branch of the Civil Division, Civil Appellate, and individual U.S. Attorney's offices that prosecute and defend national security cases within their individual districts. See infra note 93.

50. See, e.g., Herbert A. Simon, Why Public Administration?, 8 J. PUB. AdMIN. REs. \& THEORY 1, 10 (1998) (highlighting "the importance of organizational loyalty and the processes of organizational identification in shaping the behavior of people when they are acting in their organizational roles" (footnote omitted)).

51. See, e.g., CHAYES, supra note 14, at 30 ("Legal considerations... filter[] through the different purposes, perspectives, and susceptibilities of the players in the central game."); Magill \& Vermeule, supra note 37, at 1037-38 (discussing various types of stakeholders who may exert "decisive or crucial authority" over agency action, and who "are likely to disagree, at least sometimes, about the right course for the agency" (footnote omitted)); Rao, supra note 15, at 228 ("[E]ach agency has a particular culture and institutional interests that shape how it provides legal analysis.").

52. Rao, supra note 15 , at 228.

53. See, e.g., Harold Koh, Protecting the Office of Legal Counsel from Itself, 15 CARDOzo L. REV. 513, 515 (1993) (highlighting the difference in potential impartiality between legal guidance given ex ante versus ex post, when the lawyer would be "locked into a position by [the] client's action and forced to ... justify[] that action after the fact").

54. Id.

55. See, e.g., W. RICHARD SCOTT, ORGANIZATIONS: RATIONAL, NATURAL, AND OPEN SYSTEMS 278-79 (1981) ("[P]ositions are filled by persons, and persons possess diverse and variable characteristics, some of which may become the basis for informal power differences in formal organizations.").

56. See, e.g., Goldsmith, The Terror Presidency, supra note 14; SCHARF \& Williams, supra note 12, at 192-93 (quoting Legal Adviser William Taft as stating that had the Legal Advisor been 


\section{Interpretation Catalysts Trigger Different Mechanisms for Decisionmaking}

Considering this multitude of deciders within the executive and the inevitability of disagreement among them, how does the executive ever arrive at a position? In fact, diverse mechanisms exist throughout the executive for coordinating and corralling decisionmaking. These distinct methods of decisionmaking determine the forum in which decisionmaking will occur, the method of coordination and where the ultimate decisionmaking authority will lie. Thus, different mechanisms elevate and empower different sets of actors, and affect the contextual pressures emphasized, the interests prioritized, and the formality of decisionmaking authority. These different mechanisms for coordination click into gear depending on the interpretation catalyst that triggers the decisionmaking process. For example, the filing of a lawsuit against the United States will trigger a litigation-coordination mechanism for determining the executive's legal position and response.

Mechanisms for coordination of decisionmaking take many forms. Legislation or executive orders may delegate formal structural coordinating or decisionmaking authority to a task force or given office, such as National Security Council (NSC)-led working groups and committees. ${ }^{57}$ In other cases mechanisms for coordination and ultimate decider status may arise organically, such as the SG-led process for gathering agency views and reaching a litigation position. ${ }^{58}$ Who decides a given question may be linked to who has "the pen" on that issue, or whose agency intends to take an action or enforce a particular policy. ${ }^{59}$ If a U.S. military commander is making an urgent capture decision in the field, questions regarding the executive's detention authority under the laws of war will likely take a different path up through the government (and they

involved in the legal work involving treatment of detainees, "several conclusions that were not consistent with our treaty obligations under the Convention against Torture and our obligations under customary international law would not have been reached"). Of course, there are some issues-of which this may be an example-where high-level officials (including the President) are sufficiently involved and invested in a given result so as to make the particular process followed carry less weight. See M. Elizabeth Magill, Can Process Cure Substance? A Response to Neal Katyal's "Internal Separation of Powers," 116 YALE L.J. POCKET PART 126, 130 (2006), http://yalelawjournal.org/images/pdfs/73.pdf (arguing that "the Bush Administration's post-September 11 legal decisions [were not] the result of a failed process," rather "the Administration's decision-makers were aware of the opposing arguments but adopted the course that they did despite those objections").

57. See, e.g., BAKER, supra note 45, at 107-08, 116-19 (describing NSC-run Principals and Deputies Committee Meetings as the principle "interagency for[a] for consideration of policy issues affecting national security," which "frame issues for presidential consideration or resolve issues that do not require presidential decision," as well as informal mechanisms for National Security Advisor-run high level meetings); Robert Chesney, Podcast Episode \#8: Brigadier General Richard Gross on the Role of the Legal Advisor to the Chairman of the Joint Chiefs of Staff, LAWFARE (Apr. 9, 2012, 2:23 PM), http://www.lawfareblog.com/2012/04/lawfare-podcast-episode-8-brigadier-general-richard-gross -on-the-role-of-the-legal-advisor-to-the-chairman-of-the-joint-chiefs-of-staff (discussing NSC-led meetings, in addition to "Lawyers Group" meetings run by the National Security Legal Adviser).

58. See infra Section III.A.

59. See, e.g., Stephen Preston, Remarks at Harvard Law School: CIA and the Rule of Law (Apr. 10, 2012), http://www.lawfareblog.com/2012/04/remarks-of-cia-general-counsel-stephen-preston -at-harvard-law-school/\#more-6709 (explaining the process for legal decisionmaking in areas where the CIA has the lead). 
may not get very far up even within the individual's immediate chain of command), than similar questions arising in Guantánamo habeas litigation in federal courts, where DOJ litigators must make public representations in briefs that are vetted throughout the interagency, but on which DOJ-not DOD-has final authority. ${ }^{60}$

OLC, for its part, takes on a critical role in coordinating and settling legal interpretation for the executive in certain contexts. This intimate office of twenty or so attorneys ${ }^{61}$ is unusual in many ways, not the least of which are the formal legal opinions its attorneys produce, which are generally considered binding on the relevant components of the executive. ${ }^{62}$ Yet OLC has significant constraints on its involvement in decisionmaking. First, while OLC has developed an expertise in strict legal interpretation, questions of legal policy may be ill-suited to the office. ${ }^{63}$ Moreover, outside of certain specific matters, ${ }^{64}$ OLC's authority depends on agencies' willingness to turn to the office for guidance. ${ }^{65}$ Agencies may choose to do so for a number of reasons, including to seek heightened legitimacy and broader accountability-even political or legal cover-for controversial policies or actions. ${ }^{66}$ But there are many reasons

60. See, e.g., infra Subsection III.A.2.c.

61. OLC is run by a political appointee and staffed by several political deputies and career attorneys, many of whom turn over with some regularity. There exists some debate over whether the office is properly characterized as predominantly "career" or political. See, e.g., Cornelia T.L. Pillard, The Unfulfilled Promise of the Constitution in Executive Hands, 103 MiCH. L. REV. 676, 703 (2005) (arguing that OLC is "staffed largely with career lawyers whose principal credentials are their legal skills, and have tended to foster within their own legal cultures a distinction between politics and law"); Rao, supra note 15, at 244 (arguing that this "structure of OLC allows for a significant degree of political control over the office").

62. See, e.g., Exec. Order No. 2877 (May 31, 1918), reprinted in WASH. Gov'T PRINTING OFFICE, TRADING WITH THE ENEMY ACT AND AMENDMENTS THERETO 48 (1920) ("[A]ny opinion or ruling by the Attorney General upon any question of law ... shall be treated as binding upon all departments, bureaus, agencies or offices therewith concerned."). But see Herz, supra note 12, at 171 n.13 (suggesting that "uncertainty reigns as to the present validity of this order" but that the issue "need never come to a head" because submission to OLC guidance is voluntary and, "even under EO 2877, agencies are not required to submit legal questions to the attorney general").

63. See, e.g., Pillard, supra note 61 , at 704 .

64. Certain matters such as pending legislation and executive orders almost always pass through the OLC for legal advice and approval. See Office of Legal Counsel: General Functions, 28 C.F.R. $\S 0.25$ (2010); Office of Leg. Counsel, About the Office, U.S. DEP'T OF JUST., http://www.justice.gov/olc (last visited Mar. 12, 2012). Other matters may, due to their substance, carry an expectation of OLC involvement. See Morrison, Alarmism, supra note 7, at 1732-33 ("[Q]uestions that should ordinarily go to OLC . . cover (1) legal issues that OLC has a history of addressing and on which it therefore has an accumulated jurisprudence and expertise; (2) significant issues of executive power; and (3) programs or policies likely to trigger substantial public attention and/or controversy.").

65. See, e.g., Herz, supra note 12, at 161 . Herz notes that while OLC gives

a binding legal opinion to an agency ... [i]n a relative handful of cases, ... this fact hardly means that the department controls legal advice-giving. Most importantly, it cannot insist on giving an opinion on a question of law facing the agency; the agency must come to it. As a result, the agency holds its own counsel on the huge majority of legal issues, without advice from the OLC.

Id.; see also Pillard, supra note 61, at 713 ("Nobody is required to seek a legal opinion from OLC. Each potential client agency, department, or office has its own lawyers and they are free to resolve issues, including constitutional issues, on their own.").

66. See, e.g., GOLDSMITH, THE TERROR PRESIDENCY, supra note 14, at 96-97 (explaining that OLC opinions can offer "legal cover" for officials who fear prosecution for risky actions and policies, 
agencies may not wish to seek OLC advice. Not least among them are the following: they might not like the answer they expect to receive from OLC, ${ }^{67}$ or they may not wish to subordinate the decisions of their own agency officials to those of OLC attorneys. ${ }^{68}$ To date OLC plays a considerable role in executive legal interpretation, but this office has structural and substantive constraints on how much it can address and control, the ways legal decisions come to it and its ability to weigh in or direct decisionmaking, and its expertise relative to the agency lawyers who regularly operate in given fields; it thus complements but does not displace or control the vast universe of legal decisionmaking that occurs daily throughout the executive bureaucracy. ${ }^{69}$

Decisionmaking mechanisms often are not set in stone and authority can evolve over time or change with new administrations as they issue new regulations and executive orders. This potential for fluctuation has at times resulted in turf battles between the agencies over legal interpretation. For example, DOJ has sparred repeatedly with the State Department's Office of Legal Adviser (L) over control of international law interpretation and representation, ${ }^{70}$ leading at times to intervention by White House staff and even on occasion by the President himself. ${ }^{71}$ Some can be explained by true

because OLC opinions are "effectively an advance pardon for actions taken at the edges of vague criminal laws"); Morrison, Libya, supra note 7, at 63 ("When OLC concludes that a government action is lawful, its conclusion carries a legitimacy that other executive offices cannot so readily provide.").

67. In fact, OLC is sometimes asked not to prepare a formal opinion on a matter. See, e.g., Pildes, supra note 8, at 1399 (noting that "one will never see an OLC memo reaching th[e] conclusion ... [that] Congress did have the constitutional power to" constrain the President's wartime authority in an "unprecedented" manner, because " $[t]$ he White House would neither need nor want" such a memo); Pillard, supra note 61, at 716-17 (stating that "the more critically OLC examines executive conduct, the more cautious its clients are likely to be in some cases about seeking its advice"; thus OLC's reliance for its jurisdiction on decisions being brought to it by "the potential objects of constitutional (or statutory) constraint" themselves dilutes its power as a constraining force).

68. See, e.g., Herz, supra note 12 , at 161 .

69. The OLC, too, may be overruled by the President, though such an act would be "exceedingly rare," and the structure of the relationship and its public image make that a significant decision for any President. See Dawn E. Johnsen, Faithfully Executing the Laws: Internal Legal Constraints on Executive Power, 54 UCLA L. REv. 1559, 1577-78 (2007) (explaining that "OLC's legal interpretations typically are considered binding within the executive branch, unless overruled by the attorney general or the President (an exceedingly rare occurrence)").

70. See, e.g., The Attorney General's Role as Chief Litigator for the United States, 6 Op. O.L.C. 47, 61 (1982) (noting a dispute between DOJ and L over representation of the United States before the International Court of Justice, and asserting the Attorney General's authority over both domestic and international litigation); SCHARF \& WILLIAMS, supra note 12, at 52-54, 57 (quoting former Legal Advisers Robert B. Owens's and Davis R. Robinson's discussions of L-DOJ turf battles over interpretation of treaties and customary international law, as well as ICJ litigation).

71. See, e.g., Memorandum from Edwin Meese III, Counselor to the President, to the Sec'y of State, and the Sec'y of Treasury, (Feb. 19, 1982) [hereinafter Memorandum from Edwin Meese] ("The President, being aware of relevant facts and having considered the stated positions and arguments urged by the Attomey General and by the Secretary of State, has concluded that for foreign policy reasons the best interests of the United States require that the Secretary of State, subject to the President's prerogative, will continue to designate agents to represent the United States and will continue to control proceedings before international tribunals. The President is aware of the Attomey General's practice of providing assistance to the Secretary when requested in particular proceedings before intemational tribunals, and approves such practice."); see also Morrison, Alarmism, supra note 7, at 1738 (discussing Secretary of State Colin Powell's request that President Bush reconsider his reliance on a formal written OLC opinion advising that al Qaeda and Taliban detainees did not merit prisoners of war protection 
difference of opinion over legal substance, such as the L-OLC debate over the treatment of detainees in the early years of the Bush Administration. ${ }^{72}$ Others might have more to do with structural concerns, as may have been the case with respect to the L-DOJ struggle over control of international litigation during the early 1980 s. $^{73}$

In some cases, a formal mechanism may initially engage, but events or actors may intervene to move the process into a different forum. Examples of this include the initial White House Counsel-convened and State Departmentled interagency process to determine how to try detainees captured in the conflict with al Qaeda, which according to then-National Security Adviser Condoleezza Rice's account was deflected by the press of ongoing events and internal power wrangling into a process that circumvented the established national security and foreign policy players such as NSC and the State Department. ${ }^{74}$ Likewise, upon taking office, President Obama issued several executive orders mandating formal processes to examine, inter alia, the scope of the executive's military detention authority and the detainability of individuals held at Guantánamo. ${ }^{75}$ Yet many of the thorniest legal questions were overtaken by the crush of ongoing detainee habeas litigation, ${ }^{76}$ in which the executive was forced to declare views on such critical issues as the lawful scope of military detention in the instant conflict, procedures for review of detainees, the nature of the "enemy" groups with whom it was at war, and even the geographic and temporal scope of the conflict. ${ }^{77}$ Thus the Administration's positions on some of the most important legal questions of the current conflict were largely formed not through the task forces designed to address them but through the litigation coordination process. ${ }^{78}$ In contrast, statements by

under the Geneva Conventions and the fact that White House Counsel Alberto Gonzales "went out of his way to stress that 'OLC's interpretation of this legal issue is definitive'").

72. See supra note 56 .

73. See Memorandum from Edwin Meese, supra note 71.

74. CONDOlEezZa Rice, No Higher HoNOR 104-06 (2011).

75. Exec. Order No. 13,493, 74 Fed. Reg. 4901 (Jan. 22, 2009).

76. Deadlines in the then-continued military commissions cases also likely affected reforms of the military commissions system. See Press Release, The White House Office of the Press Secretary, Statement of President Barack Obama on Military Commissions (May 15, 2009), http://www.nytimes.com /2009/05/15/us/politics/15obama.text.html.

77. See, e.g., Respondents' Memorandum Regarding the Government's Detention Authority Relative to the Detainees Held at Guantanamo Bay, In re Guantanamo Bay Detainee Litigation, $577 \mathrm{~F}$. Supp. 2d 312 (D.D.C. 2009) (No. 08-442) [hereinafter March 13 Brief] http:/www.justice.gov/opa /documents/memo-re-det-auth.pdf (asserting the Obama Administration's revised standard for detention authority of individuals detained at Guantánamo). Reports suggest that the President took an unusual level of interest in this initial March 13 brief, thus altering the typical litigation dynamic. Yet, as Daniel Klaidman notes, litigation subverted the forum in which this initial decision would be made. DANIEL KLAIDMAN, KILl OR CAPTURE: THE WAR ON TERROR AND THE SOUL OF THE OBAMA PRESIDENCY 58. 60 (2012) (trumpeting the President's role in the March 13 brief and discussing the driving pressure of litigation, yet glossing over areas of significant continuity from the prior Administration's legal position). Moreover, hundreds of subsequent filings in the Guantanamo habeas cases-which the President could not monitor-addressed and disposed of many significant legal questions. See, e.g., Bensayah v. Obama, 610 F.3d 718 (D.C. Cir. 2010) (addressing the reach of detention authority to an individual who had been apprehended in Bosnia, far from a traditional "hot" battlefield).

78. See KLAIDMAN, supra note 77 . 
government officials suggest that the Obama Administration significantly restructured the decisionmaking process regarding certain decisions to use force, in particular targeted killing, in the conflict with al Qaeda, including ensuring that such decisions would be made only at the highest levels. ${ }^{79}$ These examples demonstrate that diverse deciders and processes have existed over time, and that Presidents and other actors can and do change the structure of legal interpretation to some extent in order to seek better or different substantive outcomes, but that external events and other interpretation catalysts can play an aggressive role in radically altering the shape of the decisionmaking process.

At the highest levels, meetings of cabinet secretaries or their deputiestypically called Principals Committees or Deputies Committees-can be called to coordinate and decide matters, or to tee up a final decision for the President. ${ }^{80}$ Typically these will be questions of policy and not strict legal interpretation, though legal decisions and considerations will certainly inform and constrain the policy options. Yet few decisions reach this level, and when they do they arrive in a packaged form, interwoven with multiple considerations, which frames the available choices. ${ }^{81}$ Similarly, in any of these mechanisms, the President may step in to overrule the decision of an agency or of other advisers, with varying consequences depending on the circumstances, the nature of the dispute, and the temperament of the relevant officials (including willingness to resign or leak information). ${ }^{82}$ But this is almost always unrealistic as a practical matter. For the President to weigh in on an issue, it requires first and foremost that it be brought to his attention and in a sufficiently timely matter. Yet it is unlikely the President himself is even aware of the vast majority of the legal decisions that occur regularly throughout the executive. Moreover, if the matter comes to the President not as a neutral choice among options but rather as a question whether to "overrule" the decision of one of his cabinet members or advisers, this very form has an impact on the outcome and the weight given to that particular decision. ${ }^{83}$ And even when a matter does come before a President who then signs off on one proposal over another, how and to what extent this decision is interpreted and then implemented depends once again on multiple layers of bureaucratic

79. See, e.g., John Brennan, Assistant to the President for Homeland Security and Counterterrorism, The Efficacy and Ethics of the President's Counterterrorism Strategy (Apr. 30, 2012), http://www.wilsoncenter.org/event/the-efficacy-and-ethics-us-counterterrorism-strategy (noting the evolution in the Administration's procedures and standards with respect to targeted killings, which are now "evaluated by the very most senior officials in our government for decision"); KLAIDMAN, supra note 77 , at $42-43$.

80. See, e.g., BAKER, supra note 45, at 107-08, $116-19$ (describing NSC-run Principles and Deputies Committee meetings as the principal "interagency for[a] for consideration of policy issues affecting national security," which "frame issues for presidential consideration or resolve issues that do not require presidential decision," as well as informal mechanisms for National Security Advisor-run high level meetings (citations omitted)).

81. See supra notes $45-46$.

82. See, e.g., GOLDSMITH, THE TERROR PRESIDENCY, supra note 14.

83. See, e.g., Morrison, Libya, supra note 7, at 68-69. 
players who may or may not share the exact vision of the President or understanding of his intent. ${ }^{84}$

Decisionmaking processes vary dramatically across a range of factors, and each promotes different types of decisions. As this Article will explore in Parts III and IV, some interpretation catalysts trigger processes that focus on consensus; others promote unitary deciders. Some permit extensive reflection; others demand immediate decisions. Some tend to engage high-level officials while others empower career bureaucrats. Some further entrench the status quo while others are more conducive to change. All of these factors are predictable according to the interpretation catalyst and resulting decisionmaking mechanism at issue, and will heavily influence the ultimate executive position. Understanding how these catalysts operate is thus essential to comprehending executive action or influencing an administrative agenda.

How a given legal decisionmaking process is triggered, and the distinctive pressures, players, and likely influences that come along with it, are addressed in the following Part, which examines these phenomena through the exploration of three distinct interpretation catalysts.

\section{THE ROLE OF INTERPRETATION CATALYSTS IN SHAPING EXECUTIVE BRANCH LEGAL DECISIONMAKING}

Interpretation catalysts come in many forms. They can trigger quite specific, narrowly-tailored questions: can DOD lawfully use military force to target this individual in Pakistan? They can also involve broad, open-ended hypotheticals, such as a White House request to determine the scope of options legally available to the President on a given matter. They may trigger guidance that is more or less formal; that is public or secret; that can involve mere flagging of legal risk or clear establishment of legal boundaries; or that may promote legal policy that is informed by law but does not necessarily require formal legal decisions.

This Part explores in detail three key interpretation catalysts-defensive litigation, the treaty-body reporting process, and speechmaking-in order to illustrate the effect of catalysts on internal executive processes and players. This list is not intended to be exhaustive and represents only a fraction of the countless interpretation catalysts that regularly impel executive action. ${ }^{85}$ Because of the difficulty in assessing secret or simply informal legal interpretation-indeed, legal guidance often heads off policy options at such an

84. A classic anecdote recalls President Harry Truman's prediction of then General Dwight Eisenhower's adjustment to the Presidency: "He'll sit here, ... . and he'll say, 'Do this! Do that!' And nothing will happen. Poor Ike-it won't be a bit like the Army. He'll find it very frustrating." PETER W. Rodman, PRESIDENTIAL COMMAND: POWER, LEADERSHIP, AND THE MAKING OF FOREIGN POLICY FROM RICHARD NIXON TO GEORGE W. BUSH 5 (2009). As for his own experience, Truman reflected, "I sit here all day trying to persuade people to do the things they ought to have sense enough to do without my persuading them.... That's all the powers of the President amount to." Id.

85. See supra note 29 . 
early stage that the need does not arise for a final opinion ${ }^{86}$-this Part focuses on three catalysts that involve both formal crystallization and public declaration. By necessity this removes some interesting variables from our study-for example, we cannot assess here the effect secrecy has on decisionmaking. ${ }^{87}$ Nevertheless, sufficient differences remain between these public examples of interpretation catalysts to illustrate the phenomenon. And one can hypothesize that a broadening of the exercise to examine the full range of legal decisionmaking-in particular the addition of variables such as level of transparency and formality of guidance-would only heighten, rather than weaken, the interpretation catalyst effect.

This Part will examine the unique nature of each catalyst according to the following metrics, which can dramatically shape the ultimate decision: the effect of the catalyst on which component of the executive or type of official takes the lead on decisionmaking; its effect on the mechanisms for coordination employed; and the contextual pressures and distinctive utility of each catalyst.

\section{A. The Defensive Litigation Catalyst}

Filing a lawsuit against the government has historically been a natural means by which to challenge executive action or policies. Defensive litigation in U.S. courts is therefore a particularly significant catalyst driving the executive regularly to state its legal position publicly on matters of national security. It has a variety of important effects on the executive; it may serve to bring matters into the public view, to prompt policy change, or to force the executive branch to crystallize its views publicly. But contrary to conventional wisdom, which holds that it is also a means of pushing the executive to confess error and accept legal obligations, ${ }^{88}$ in the area of national security, defensive litigation is not often an effective means of binding the executive branch to a more constrained interpretation of its legal authority. In fact, for reasons explored in the following sections, the contrary is often true.

With some critical exceptions over the course of the last decade ${ }^{89}-$ notable mainly for their rarity-U.S. courts tend to defer broadly to the

86. See, e.g., Pildes, supra note 8, at 1398-1400 (arguing that constraining opinions may inform decisions but are unlikely to be formalized).

87. See, e.g., Morrison, Alarmism, supra note 7, at 1730 (suggesting that secret opinions more easily permit politicized advice on high-priority matters). Certainly notorious examples exist of formerly-secret, aggressive lawyering. But, as Pildes notes, we are unlikely ever to see the many examples of secret, constraining lawyering. Pildes, supra note 8, at 1398-1400. Nevertheless it might be revealing to study historical examples of legal guidance that eventually came to light despite their intended nondisclosure, though even this sample would be skewed toward decisions that were formalized in writing and thus might not sufficiently include the kind of constraining advice Pildes suggests often goes unmemorialized.

88. See, e.g., Pillard, supra note 61 , at 709.

89. See, e.g., Boumediene v. Bush, 553 U.S. 723 (2008) (extending the writ of habeas corpus to aliens detained at Guantánamo); Hamdan v. Rumsfeld, 548 U.S. 557 (2006) (defining the conflict with al Qaeda as a non-intemational armed conflict to which Common Article 3 of the Geneva Conventions would apply, contrary to the prior stated position of the U.S. government). 
executive in areas of wartime authority, foreign policy, and national security. ${ }^{90}$ This means that the executive's interpretation of its legal authority in a given case-where it may be called upon to craft its position in the course of that litigation-is given enormous weight and often becomes the law of the land. Yet the impact of litigation on the ex ante executive legal decisionmaking process cannot be overstated. This impact is particularly salient when when the government or government officials are a defensive party to the suit. ${ }^{91}$ Once the government is implicated in a lawsuit, particularly over a matter of national security, nearly all forces align to push the executive to advocate an expansive view of its own authority, to defend past action, and to request a judgment in favor of the government on the broadest possible grounds so as to preserve executive flexibility to the greatest possible extent.

\section{Who Has the Pen?}

A critical effect of litigation on legal interpretation within the U.S. government is its influence on the players involved and their stature at the decisionmaking table. As this section shows, litigation has a radical effect on decisionmaking authority. It shifts authority among agencies-toward DOJ and away from the client agencies whose policies may be at stake. And it shifts authority within DOJ itself, toward the litigating components such as the SG's office and the Civil Division, and away from policy offices and OLC.

Domestic litigation authority is for the most part consolidated today in DOJ. ${ }^{92}$ DOJ itself is made of many components, and which component takes the lead on a given issue depends on its substance and the task at hand. The Solicitor General not only represents the United States in the Supreme Court, but also has authority over whether to pursue appeals in cases lost by the government in lower courts, when to intervene or file amicus briefs in all appellate courts, and whether and when to defend the constitutionality of congressional statutes. ${ }^{93}$ Responsibility for other national security litigation is peppered throughout various offices according to the nature of the case. Thus,

90. See, e.g., Pillard, supra note 61 , at 692 (citing cases).

91. A comparison of the executive's position in defensive cases with those in which it is bringing suit or where it or a government official is not a named party would be worth exploring. In the interest of brevity this Article focuses on defensive lawsuits. Ingrid Wuerth has noted a potentially distinct effect of litigation on executive branch positions in the context of state immunity. See Ingrid Wuerth, International Law in Domestic Courts and the Jurisdictional Immunities of the State Case, 13 MELBOURNE J. INT'L LAW 819, 834 (2012) (noting that "executive branches may feel constrained in domestic litigation in ways that might not reflect their preferences when they engage in state-to-state negotiation").

92. See, e.g., 28 U.S.C. $\S 516(2006)$ ("Except as otherwise authorized by law, the conduct of litigation in which the United States, an agency, or officer thereof is a party, or is interested, and securing evidence therefor, is reserved to officers of the Department of Justice, under the direction of the Attorney General."); Herz, supra note 12, at 149 (noting some exceptions to DOJ control but stating that, "[f]or all intents and purposes, it is accurate to say that the Department of Justice represents executive agencies in court"). The State Department generally controls litigation before international tribunals. See Memorandum from Edwin Meese, supra note 71.

93. Salokar, supra note 10, at 67-75; Office of Solicitor Gen., About the Office, U.S. DEP'T OF JUST. (last visited Apr. 1, 2013), http://www.justice.gov/osg/about-osg.html. 
while a particular legal question such as the applicability of a human rights treaty to detainees at Guantánamo might have relevance for a range of cases, the context in which this question arises-for example, whether in a GTMO habeas or Bivens case-affects the office that will exercise general control over the executive's position. ${ }^{94}$

One of the most significant characteristics of litigation is that the career attorneys who are tasked with managing particular cases in practice wield a significant amount of authority. ${ }^{95}$ First, career litigators typically draft the briefs, which can itself matter a great deal, particularly when substance turns on nuances in language. As with any negotiation, the person drafting the language wields authority simply by setting the default against which others must argue. Other actors who might wish to challenge particular language therefore find the stage already set against them, and they must pick their battles in what they will try to change in the brief, what they can live with, and what they will agree to compromise, starting from the position of the initial draft crafted by the line attorney. The position as drafter affects not only that initial negotiation but all subsequent discussions and compromises as well because, more often than not, that attorney will be tasked with drafting the language to implement the compromise, and thus remains in a position to influence the ultimate position.

Second, the often crushing timetable of litigation-particularly at the trial level - at times simply does not permit extensive negotiation and elevation of policy or legal questions to several layers of superiors within the agency. Questions may arise on short notice in briefing, and even shorter notice when presented by a judge during oral argument. The line attorney must therefore be permitted a certain degree of discretion in presenting the government's position to the court.

Moreover, the unique nature of litigation and the specific expertise as well as ethical duties of litigators-who must present themselves in court, may risk sanctions for objectionable behavior or frivolous arguments, and interact regularly with the trial and appellate judges and thus are best placed to gauge the impact that particular arguments might have on the outcome of a caseprovide individual career litigators with a certain measure of institutionalized power to stand up to political pressure or scrutiny over their legal positions. The power of these individual litigators is potentially greater than that of their colleagues in other offices, who do not always have the threat of an adverse

94. For example, Federal Programs handles Guantánamo habeas litigation and the Torts Branch handles damages claims brought by detainees alleging mistreatment. See Civil Division: General Functions, 28 C.F.R. $\S 0.45$ (2012) (vesting in the Civil Division responsibility for defense of tort suits against the United States and other civil litigation); March 13 Brief, supra note 77. The National Security Division itself was created in March 2006 by the USA PATRIOT Improvement and Reauthorization Act of 2005 to consolidate other offices handling intelligence and counterterrorism issues, but does not handle much litigation. See USA PATRIOT Improvement and Reauthorization Act of 2005, Pub. L. No. 109-177, 120 Stat. 192 (2006); National Security Division, 28 C.F.R. $\S 0.72$ (2012); Nat'l Sec. Div., About the Division, U.S. DEP'T OF JUSTICE, http://www.justice.gov/nsd/about -nsd.html (last visited Apr. 1, 2013).

95. See, e.g., WILSON, supra note 20, at 27 (noting that "rank-and-file employees" often have "a great deal" of "discretionary authority"). 
judicial decision to use against political interference. ${ }^{96}$ The anti-politicization culture at DOJ that engenders chafing at White House interference also trickles down to affect the political appointee-career litigator dynamic as well. ${ }^{97}$ of course, career attorneys at DOJ are not free from political or supervisory control or pressure, but they do benefit from unique institutionalized norms that permit the line attorney more authority and discretion than he might otherwise have in a different agency or context. ${ }^{98}$

\section{Mechanisms for Coordination and Decision}

The defensive litigation catalyst is a highly effective trigger of decisionmaking within the executive branch that, because of the aggressive, externally driven timetable and significant risks involved, tends to trump more comprehensive means of coordination. The litigation catalyst can force the executive branch to formulate and state a legal interpretation that it otherwise might not have resolved internally, or might not have stated publicly; in other cases it can change the internal process in which such resolution is already taking place, driving it instead into the litigation-coordination forum.

\section{a. Interagency Engagement on Litigation}

Consolidation of litigating authority in DOJ does not mean that the role of other agencies and their respective general counsels (or for that matter the nonlitigating offices of DOJ) ends where litigation begins. Such offices-in particular "client" agencies-may have enormous stake in the case at hand. Interagency offices relevant to a particular matter continue to play a role in the process and may even be asked to help develop the government's position or strategy or to review briefs, though DOJ retains control of the process. ${ }^{99}$

Interagency discussion may take a variety of forms. Supreme Court and appellate litigation advances on a timetable that generally permits somewhat

96. See, e.g., Neal Devins \& Saikrishna Prakash, The Indefensible Duty To Defend, 112 COLUM. L. REV. 507, 540 (2012) ("DOJ embraces norms and traditions that enhance the status and autonomy of the Department and its attorneys [allowing them] to see themselves as lawyers for "the United States ... and not [for] the particular President who happens to be serving." (quoting Maureen Mahoney, et. al., Solicitors General Panel on the Legacy of the Rehnquist Court, 74 GEO. WASH. L. REV. 1171,1180 (2006) (comments of Walter E. Dellinger))); Pillard, supra note 61, at 728 (arguing that SG and OLC independence derives from judicial involvement).

97. See id.

98. See id.

99. See, e.g., GREGORY C. SISK, LITIGATION WITH THE FEDERAL GOVERNMENT 4 (4th ed. 2006) (stating that " $[t]$ he Department of Justice makes the decision on litigation strategy, with the advice-but not the control-of the client agency"; in contrast to private litigants, "federal government entities are 'captive clients' who are unable to "fire' the Department of Justice as litigation counsel"); Magill \& Vermeule, supra note 37, at 1060 ("When a DOJ attorney represents the agency in court, the agency (and its general counsel) loses sole control over the arguments it will make and the tactics it will pursue in defending or pursuing agency action. Agency officials will instead need to persuade the DOJ lawyer that the agency's views on substantive matters or litigation tactics are correct."). 
formal interagency input and deliberation. ${ }^{100}$ In making decisions regarding litigation positions or whether to appeal or seek certiorari in a case, the SG tends to solicit written views from the relevant agencies, holds interagency meetings to discuss these views, and acts as the ultimate decider in determining the government's course of action. ${ }^{101}$

With respect to litigation at the trial level or other initial decisionmaking, staff attorneys throughout the relevant agencies may coordinate with DOJ litigators both through formal interagency meetings and through less formal phone calls and email exchanges over strategy, legal positions, declarations from government officials, and even specific language in briefs. To the extent any disagreements cannot be resolved at this level, individuals may ask to "elevate" a particular issue, meaning they may raise it with superiors within their own agencies, or they may request a higher level of scrutiny at DOJ, or both. The most important matters-or intractable disagreements-may eventually find their way to the SG or the Attorney General. ${ }^{102}$ And if there are significant policies at stake or questions over which the Attorney General would like other input (or political cover), he or she may bring the question to other Cabinet- or sub-Cabinet-level officials. Nevertheless, as the next two sections explore, there are both practical and structural limits to coordination.

\section{b. Limits to Coordination}

There will always be matters that may be decided by one particular official or agency (or some subset of agencies) with limited recourse to other actors in the executive. The reasons for this limited recourse may turn on the nature of the matter, its significance, already-adjudicated status (perceived or actual), the practical reality of time constraints and other pressures, or a simple cutting out (intentional or not) of actors outside that agency. Litigation decisions often involve combinations of several of these factors.

First, the intense timetable of litigation alone may obstruct extensive coordination. All of the deliberation, elevation, and negotiation discussed above must happen in accordance with hard and often very short litigation deadlines. Thus, even to the extent a number of agencies may in their view have legitimate concerns with a particular litigation position, they may face an uphill battle to elevate these concerns to higher-level officials in the race against the clock. And it is a clock over which DOJ, as the agency directly holding the pen, inherently exercises more control than the other agencies.

In addition, litigators at DOJ regularly file briefs that follow similar language and legal interpretation of a given issue agreed upon by the interagency and political superiors for use in prior briefs, but adopted for a new

100. See, e.g., Devins \& Prakash, supra note 96, at 542 ("[T]he Solicitor General makes use of a court-like process in which affected agencies submit written analyses and participate in meetings in which they 'advocate' their position to the Solicitor General.").

101. Id.

102. See, e.g., Pillard, supra note 61. 
case or issues. In such a scenario, there may be a decision not to reengage the rest of the interagency or DOJ hierarchy either due to an assumption that such language would be accepted for all cases going forward, or to a disinclination to rehash the arguments leading to the prior compromise. Or there may be an assumption by career lawyers that prior clearances and redlines continue to apply despite a shuffling in the political players, and therefore a neglect to reclear positions before taking them in court. Indeed, practical reasons alone make it untenable to engage actors throughout the rest of DOJ and the interagency over the drafting of every sentence in every brief that litigators might file. Yet it is inevitable that even small exercises of discretion will invariably lead to some subset of cases where new interpretations-however slight-may be taken, and these micro-positions can over time entrench legal positions.

\section{c. DOJ as Decider}

Moreover, despite often extensive coordination with client agencies over litigation positions, if there remain disagreements over how to handle a case, DOJ litigators (and formally, the Attorney General) have the final say. ${ }^{103}$ The AG's litigation authority is delegated to specific litigating offices within DOJ, such as OSG, ${ }^{104}$ the Civil Division ${ }^{105}$ and other components of DOJ. The SG generally exercises ultimate control over matters within his authority, which can mean overruling an agency view or resolving a dispute between agencies. ${ }^{106}$ In this and other matters, if a matter is elevated either within DOJ or by interagency players, the AG may weigh in personally, though he or she is unlikely to interfere in matters under the SG's authority. ${ }^{107}$ And once the AG makes a final decision about a legal position or choice of appeal, only the President may overturn that decision. ${ }^{108}$ For many reasons, including the

103. See, e.g., Donald Verrilli, Questions for the Record from Senator Orrin Hatch, submitted to the United States Senate Committee on the Judiciary, at 3 (2011), http://www.judiciary.senate.gov /nominations/112thCongressExecutiveNominations/upload/Verrilli-QFRs.pdf ("[T]he Solicitor General exercises independence within a framework that recognizes the ultimate authority of the Attorney General (and the President) - an authority rarely exercised-to decide what position the United States will take in court."); $i d$. at 7-8 ("In the event agreement cannot be reached, the Attorney General and ultimately the President have the final call." (quoting Paul Clement)).

104. Office of the Solicitor General: General Functions, 28 C.F.R. $\S 0.20(2012)$.

105. Civil Division: General Functions, 28 C.F.R. $\S 0.45$ (2012).

106. See, e.g., Symposium, Rex E. Lee Conference on the Office of the Solicitor General of the United States, 2003 BYU L. REV. 1, 73 (2003) (statement of former Deputy Solicitor General, now Chief Justice, John Roberts) ("[The interagency dispute] was resolved by holding, and this was typical, a series of interminable meetings with all interested parties that looked like nothing so much as Thanksgiving dinner at a dysfunctional family because - as you rapidly find out - these agencies have a long history of sort of squabbling with each other and now they are-it is wrong to view it this way, but-before their parents and the parents are going to decide which one gets punished and which one gets rewarded. I have always been a little surprised at the prominence of the office in resolving those types of decisions.").

107. See, e.g., Pillard, supra note 61, at 724-26 (stating that the AG "delegate[es] to the SG the framing of legal positions and, 'in the ordinary course,' permit[s] the SG's views to be dispositive" (quoting Role of the Solicitor General, 1 O.L.C. 228, 234 (1977))).

108. See supra note 103 . 
natural extra hurdle posed by a need to "overturn" a cabinet member, the entrenched culture of independence at DOJ, and the negative political repercussions that might follow were a President to be seen as overturning the $A G$ on a legal matter, presidential intervention in litigation decisions is exceedingly rare. ${ }^{109}$

\section{Contextual Pressures and Utility of the Litigation Catalyst}

As a structural matter, this Section has already explored the effect litigation has of shifting authority within the interagency toward DOJ litigators, which in itself can have an impact on substantive decisionmaking. That shift is important not only because of the individual personality of the particular players involved, but because of the unique contextual pressures of defensive litigation and thus the proclivities of the offices constituted to address that threat.

Decisionmaking by any entity in the context of litigation to which it is a party is a different animal from decisionmaking on a clean slate, or decisionmaking in one of the other fora this Article discusses. ${ }^{110}$ A single individual who suddenly faces a legal challenge in court is bound to engage that challenge reactively and defensively. As Elena Kagan and David Barron have stated, it is "natural ... to bunker down when attacked," and this is true "for agencies, no less than any other entities." 111 This is all the more true for the litigating arm of DOJ, a massive organization built in part for the purpose of defending against such challenges. As a repeat player, DOJ as an institution has over time internalized the qualities one takes on when faced with such an attack. $^{112}$ DOJ litigators structure careers around facing litigation challenges and formulating litigation positions. They are trained for these decisions, they have internalized the standards and they-like all other players in the bureaucracy-have adapted to the unique role they perform. ${ }^{113}$

109. Id: Salokar, supra note 10, at 76 (noting that the President "rarely... get[s] directly involved in government litigation"). To the extent White House staffers are engaged at an earlier stage, they may on rare occasions step in to make the views of the White House known. Also, on rare occasions DOJ may seek input from the White House, in order to receive sign-off on matters that are highly controversial or that implicate important policy considerations. See KLAIDMAN, supra note 77.

110. See, e.g., Koh, supra note 53 (explaining that, contrary to legal guidance given before action is taken, in matters pending in litigation, the "government's legal posture is already fixed by the adversary process").

111. Barron \& Kagan, supra note 28 , at 260.

112. See, e.g., ALLISON, supra note 20 , at 81 (noting that ongoing "[p]rimary responsibility for a narrow set of problems encourages parochialism" within organizations, including executive agencies, and that as a result they "develop relatively stable propensities concerning operational priorities, perceptions, and issues").

113. See, e.g., WILSON, supra note 20 , at 27 (describing how factors like the situations employees encounter and "the array of interests in which their agency is embedded... combine to produce an organizational culture-a distinctive way of viewing and reacting to the bureaucratic world-that shapes [their] discretionary authority"); Fontana, supra note 28 (explaining that civil service lawyers are not "neutral technocrats" but rather are likely to assume the proclivities and missions of their particular agencies). 
If the government is a party to litigation, it often finds itself defending past action or current policies. ${ }^{114}$ The litigator-in any context-typically arrives at a matter knowing the result he or she must reach; the task is often in determining the most persuasive way to get there. The question is not typically, "what is the best view of the law," or even "is there good legal authority for taking this action." Rather, in defensive litigation, the question is generally, "Can we reasonably argue that...?"115 The lack of a clean slate itself is of course not entirely unique to litigators. Each agency or agency component has a different perspective or standard it employs, and most have clients who wish to undertake certain actions and therefore do not operate in a vacuum. ${ }^{116}$ Litigators typically face the added hurdle of jumping into an issue once the action in question has already been taken, and of facing off against a challenge to the government and an outside arbitrator. Therefore they are not generally in a position to say, "if you do this it will entail significant risk; you should strongly reconsider." Instead they are faced with facts on the ground, and must defend them zealously if at all possible. ${ }^{17}$

Consider the position taken by the Obama Administration on the viability in military commissions of the offense of material support for terrorism: in a July 2009 statement to the Senate, then-Assistant Attorney General David Kris raised "serious questions as to whether material support for terrorism or terrorist groups is a traditional violation of the law of war," thus rendering it inappropriate for trial by military commission. ${ }^{118}$ Contrast this position with that of the government's position in its Hamdan merits brief, signed by Kris's replacement, Lisa Monaco, which - in defending the validity of Hamdan's military commission conviction-argues that material support "has long constituted a violation of the U.S. common law of war, [and] should subject the

114. See, e.g., Barron \& Kagan, supra note 28 , at 258 (arguing that the executive will ratify an earlier agency decision "in almost any case that comes before a court"); Pillard, supra note 61 , at 740 ("[T]he SG ordinarily presses plausible cases or arguments in support of governmental prerogative, without regard to whether the Constitution might be better understood to require more restraint."). It is perhaps for these reasons that courts generally decline to award Chevron deference to post-hoc litigation positions of the executive that were not established by the agency beforehand. Pillard, supra note 61, at 740 n.201; see also Magill \& Vermeule, supra note 37, at 1042 ("'A]gency action can be upheld, if at all, only on the rationale the agency itself articulated when taking action.... [A]gencies may not employ 'post hoc rationalizations' offered during litigation to save an action whose original rationale is untenable.").

115. See supra note 114 .

116. As current and former executive officials have noted, government lawyers are influenced by their role and clients' interests; in fact, a large role of a govemment lawyer is to find legal justification for a client's position to the extent possible. See, e.g., Walter Dellinger, After the Cold War: Presidential Power and the Use of Military Force, 50 U. MIAMI L. REV. 107, 109-10 (1995).

117. See, e.g., Pillard, supra note 61 , at 714-15 (noting that the SG's institutional role of "examin[ing] potential constitutional problems only after challenged government action is already a fait accompli ... create[s] incentives for the SG to interpret the Constitution to permit [the action], in order to facilitate his defense of the conduct in court-incentives that OLC [or presumably other executive actors] would not face when considering the issue in advance of [the action in question]').

118. Military Commissions: Hearing Before the S. Comm. on Armed Servs., 111 th Cong. (2009), http://www.amed-services.senate.gov/statemnt/2009/July/Kris\%2007-07-09.pdf (statement of David Cris, Assistant Att'y Gen. of the United States). 
offender to trial and punishment by military commission." ${ }^{119}$ A panel of the D.C. Circuit overturned Hamdan's conviction based on the faulty material support charge. ${ }^{120}$ Nevertheless, the government has continued to press the argument in a related case, ${ }^{121}$ allegedly even over the objections of the Military Commissions chief prosecutor, who declined to sign the briefs and recommended withdrawal of related charges in the $9 / 11$ cases. ${ }^{122}$ In fact, the contrast between that prosecutor's discretionary ${ }^{123}$ and strategic consideration over which charges to bring - even in an unquestionably more significant case-on the one hand, and DOJ's decision over whether to continue to defend an already completed conviction well illustrates the distinctive pressures of defensive litigation. ${ }^{124}$

Critical decision points arise at all stages of litigation, including at its very outset, as in the decision whether to defend a particular act or policy in the first place. For example, when federal employees are named as defendants in damages cases, the Torts Branch of the DOJ Civil Division typically handles

119. Brief for the United States at 18, Hamdan v. United States, 696 F.3d 1238 (D.C. Cir. 2012) (No. 11-1257), 2012 WL 126259.

120. Hamdan v. United States, 696 F.3d 1238 (D.C. Cir. 2012). If that decision sticks, this will be an example of a rare government loss that in principle constrains the executive's legal position. Its practical effect is less clear, as the decision applies by its terms only to legacy cases for actions taken prior to the $2006 \mathrm{MCA}$. Id. Moreover, Hamdan himself was long ago released, and other detainees with charges pending will likely remain at Guantánamo as law-of-war detainees even if they are not charged and convicted in a military commission. Ironically, Hamdan may have in fact benefited from his conviction on the faulty material support grounds; had he not be convicted and sentenced to a specific term of years, and thus released at the end of that term, he might still remain at Guantánamo as a law-ofwar detainee.

121. Supplemental Brief for United States, Al Bahlul v. United States, No. 11-1324, 2013 WL 122618 (D.C. Cir. Jan. 9, 2013), ECF No. 66; Petition of the United States for Rehearing En Banc, $A l$ Bahlul, No. 11-1324 (D.C. Cir. Mar. 5, 2013), ECF No. 69 (arguing, in a case involving the military commission conviction of a different Guantanamo detainee on charges implicated by the Hamdan decision-inter alia, material support for terrorism and conspiracy to commit war crimes-that the panel's decision in Hamdan was incorrect and should be reconsidered). On Apr. 23, 2013, the court granted the United States's petition for rehearing en banc, and oral argument is scheduled to be heard in September 2013. See also Order, Al Bahlul, No. 11 -1324 (D.C. Cir. Apr. 23, 2013), ECF No. 72.

122. Charlie Savage, US To Press Fight of Detainee's Appeal, N.Y. TIMES, Jan. 10, 2013, at A14 (stating that the chief prosecutor of the military commissions system "urged the Justice Department to drop the case and pointedly did not sign the ... brief'); Benjamin Wittes, Podcast Episode \#23: Brig. Gen. Mark Martins on His Decision To Drop Standalone Conspiracy Charges Against 911 Defendants, LAWFARE (Jan. 10, 2013, 1:48 PM), http://www.lawfareblog.com/2013/01/the-lawfare-podcast-episode -23-brig-gen-mark-martins-on-his-decisision-to-drop-standalone-conspiracy-charges-against-911-defendants.

123. In this particular example, prosecutorial discretion is limited by the commission's distinctive structure, and the convening authority for military commissions declined to dismiss the charge. See Press Release, Dep't of Defense, Convening Authority for Military Commissions Declines to Withdraw Conspiracy Charge Against Alleged 9/11 Co-Conspirators Pending Appellate Ruling (Jan.18, 2013), http://www.defense.gov/releases/release.aspx?releaseid $=15779$.

124. Although the Hamdan and Bahlul cases are not purely defensive litigation, in that government prosecutors chose initially to bring the prosecutions, the cases are nonetheless in a defensive posture at the appellate stage, as executive officials must choose whether and how to defend challenges to their convictions and to charges initially brought and framed by a politically-charged office under a prior administration. See, e.g., Benjamin Wittes, No, General Martins Has Not "Gone Rogue," LAWFARE (Jan. 27, 2013, 8:56 AM), http://www.lawfareblog.com/2013/01/no-general-martins-has-not -gone-rogue/ (noting the distinction between Martins's role in "tactical" decisionmaking "with respect to prospective prosecutions" in contrast to "the Justice Department's function with respect to completed ones"). 
the litigation. ${ }^{125}$ DOJ's decision to defend the individual is not automatic, but the stakes are high. A decision not to defend a government official for actions taken while in their official capacity can send powerful signals, not only to that individual but to other officials, about the government's willingness or ability to support their actions. Such a decision may also face intense pressure from the official's home agency, which may view a refusal to defend as an indictment of its own activities by DOJ. Thus while "[a] federal employee may retain counsel at his own expense, [] this is rarely done." 26 Yet DOJ representation means that "the DOJ attorney assigned to defend the employee enters into a "full and traditional attorney client relationship." ${ }^{127}$ Along with that representation comes a zealous defense by DOJ, ${ }^{128}$ and an understanding that this individual's defense is "in the interest of the United States." 129

It is precisely this combination of the duty of zealous defense of a client with the responsibility of speaking on behalf of the United States that makes the decision to defend so critical. For example, despite President Obama's ardent campaign against the interrogation and detention policies of the Bush administration, the new Obama Administration nevertheless found itself in the early months of 2009 defending former Secretary of Defense Rumsfeld and ten senior military officers against allegations of torture, religious desecration and other abuse, in a case brought by former Guantánamo detainees. ${ }^{130}$ Zealous defense in that case meant that-despite candidate Obama's description of Bush-era policies as an "attempt to create a legal black hole at Guantánamo" "131 - the new Administration would continue to argue that at the time of the defendants' alleged acts, it was not clearly established that the Constitution protected detainees at Guantánamo, ${ }^{132}$ and that courts should not imply a remedy for constitutional violations in the contexts of "military, national security, and foreign affairs matters that are the exclusive province of the political branches." "133 Yet it is entirely plausible that had the executive determined the reach of constitutional rights to Guantanamo in the aftermath of

125. U.S. DEP'T OF JUSTICE, U.S. ATTORNEYS' MANUAL \& 4, Ch. 4-5.100, http://www.justice.gov /usao/eousa/foia_reading_room/usam/title $4 / 5 \mathrm{mciv}$.htm ("The Constitutional and Specialized Torts Staff ... represent $[\mathrm{s}]$. . . federal employees sued, subpoenaed or charged for actions taken within the scope of their employment."); see Paul Michael Brown, Personal Liability Tort Litigation Against Federal Employees, 58 U.S. ATTORNEYS' BULL. No. 6, at 1 (2010).

126. Brown, supra note 125 , at 1 .

127. Id. at 2 .

128. For discussion of the applicability of the duty of zealous defense to government lawyers, see Catherine J. Lanctot, The Duty of Zealous Advocacy and the Ethics of the Federal Government Lawyer: The Three Hardest Questions, 64 S. CAL. L. REV. 951 (1991).

129. Brown, supra note 125 , at 1 .

130. See Suplemental Brief for Appellees/Cross-Appellants, Rasul v. Rumsfeld, 563 F.3d 527 (D.C. Cir. 2009) (Nos. 06-5209, 06-5222) WL 700175, at*8 (Nos. 06-5209, 06522).

131. Kate Zernike, McCain and Obama Split on Justices' Guantanamo Ruling, N.Y. TIMES, June 13, 2008, http://www.nytimes.com/2008/06/13/us/politics/13candidates.html.

132. See Supplemental Brief for Appellees/Cross-Appellants, supra note 130.

133. Id. at 10-11 (arguing that the court should not imply a Bivens remedy in light of "the potential for intrusion into military, national security and foreign affairs" and the likelihood that individual liability would push officials to "make decisions based upon fear of litigation rather than appropriate military policy"). 
Boumediene in a different context, and not in the extremely defensive context of defense of individual clients, the question might have been framed differently and the government might have had greater flexibility to reach a different conclusion.

Considering the significance of these decisions, the standard for choosing to defend individual defendants, as well as who makes the decision and the process for reaching it, are critical. Yet as a general matter, career line attorneys provide a "routine" review of the request for representation and approve it "as a matter of course" in "the overwhelming majority of cases." 134 It is only "difficult or novel cases," or "cases where initial review suggests the request should be denied," where additional guidance is sought from higher offices such as the Deputy Assistant Attorney General overseeing the Torts Branch. ${ }^{135}$

Likewise, DOJ has long followed a "duty to defend" policy with respect to congressional statutes. ${ }^{136}$ In accordance with this "longstanding practice," the Department defends "the constitutionality of duly-enacted statutes if reasonable arguments can be made in their defense." 137 A decision not to defend such actions is as fraught with complications as it is rare. ${ }^{138}$

Decisions to defend agency actions or policies are somewhat more complicated. There does not seem to exist a formal written doctrine for such decisions, and this is an area worthy of further exploration, but in practice the result seems to be similar to other categories of defensive decisionmaking. At the outset, DOJ litigators almost always defend agency action as matter of course $^{139}$ (and a contrary decision would likely face agency outcry over interference in agency decisionmaking). The presumption starts to wear down somewhat when the government must decide whether to appeal a loss, at which point the Solicitor General takes the reins and may exercise a greater degree of discretion in whether and how to defend the case-and may be more inclined to confess error ${ }^{140}$ - though he or she is constrained to a degree by the record of the government's involvement in the case until that point. Ultimately, the overwhelming bias is in favor of defending agency action.

Precedent, as would be expected, plays a significant role in the Department's decisionmaking, particularly when that precedent stems from

134. See Brown, supra note 125 , at 2 .

135. Id.

136. See, e.g., Daniel Meltzer, Executive Defense of Congressional Acts, 61 DuKE L.J. 1183, 1183 (2012) (exploring the historial practice of the executive branch-and "very strong presumption" of defending federal statutes).

137. See, e.g., Letter from Eric H. Holder, Att'y Gen., to John A. Boehner, Speaker, House of Representatives (Feb. 23, 2011), http://www.justice.gov/opa/pr/2011/February/11-ag-223.html.

138. See, e.g., Seth P. Waxman, Defending Congress, 79 N.C. L. REV. 1073, 1078 (2001) ("In the unique context of a constitutional challenge to legislation, the interests of the Congress and the Executive are generally pretty clear: they have spoken. And as a result, at least when those interests do not conflict with the Solicitor General's duty to the courts, the Department of Justice defends Acts of Congress in all but the rarest of cases."); see also Letter from Eric H. Holder to John A. Boehner, supra note 137 (explaining that the DOMA decision is "the rare case where the proper course is to forgo the defense of this statute").

139. See, e.g., Barron \& Kagan, supra note 28.

140. See, e.g., Pillard, supra note 61 , at 709. 
positions the executive has taken previously in court. As Paul Stephan has explained, the positions government lawyers take in court "to a certain extent, lock in their successors," and any repudiation or reversal of a prior position "come[s] at a considerable cost." change in position "generally undermines the credibility of the government's legal representatives with the courts," and the practical reality that career litigators, "will likely continue to appear before the courts even after their current political masters leave office." 142 Litigators are thus often considered a stabilizing force that reinforces a status quo against political wind shifts. There is much truth to this view, yet it does not fully account for the pressures of defensive litigation, which push litigators to view any precedent in that light. Litigation pressures can serve as a ballast, but that may at times mean simply entrenching the initially-politicized legal positions and policies of one administration, long into the next. Additionally, other executive precedent may not carry as much weight for litigators as their own positions taken in litigation; therefore in a novel lawsuit, litigation pressures may prompt a rethinking of prior executive legal positions (particularly if they were not public) toward a more aggressive view of presidential authority. ${ }^{143}$

Moreover, government litigators are moved by another set of pressures closely related to their defensive posture, which is to win the case while preserving as much flexibility as possible for the President. As repeat players, executive branch litigators cannot easily concede arguments that may permit a win in the case at hand while jeopardizing others. Thus, even in a case where litigation instincts might otherwise promote the articulation of a limited understanding of the executive's authority, litigators may be constrained in their ability to do so by other interests, such as separate ongoing litigation or even hypothetical future action. ${ }^{144}$ Tension may thus arise between the pressure to win the case and the pressure to preserve executive flexibility; the resulting decision may depend on the significance of the policies involved and the risk calculation of judicial intervention.

Defensive litigation is an aggressive catalyst for executive branch legal interpretation and policy, one that is likely to crowd out other decisionmaking mechanisms, and it can produce a great range of outcomes. These effects are not entirely retrogressive. Litigation shines a spotlight on action that may

141. Paul B. Stephan, The Limits of Change: International Human Rights Under the Obama Administration, 35 FORDHAM INT'L L.J. 488, 502 (2012) (citing Morrison, supra note 25); id. at 502 n.39 (noting that Morrison "discuss[es] the institutional stability of the executive's legal positions").

142. Id. at 502 .

143. See, e.g., Koh, supra note 53, at 519-22 (explaining how the government reversed its position on particular nonrefoulement treaty obligations in the course of litigation over the Haitian interdiction program).

144. See, e.g., Steve Vladeck, Why Hedges v. Obama Is Terribly Perplexing, LawFare (May 17, 2012, 12:33 AM), http://www.lawfareblog.com/2012/05/why-hedges-v-obama-is-terribly-perplexing (asking why -in a case involving the executive's detention authority under the 2012 NDAA-the government refused to make concessions that might have resolved the case). 
otherwise fly under the radar, forcing the executive-with muscle other catalysts do not share-to crystallize and explain publicly its legal rationale for its actions. It prompts additional layers of internal review of agency action, thus promoting interagency involvement on what might have previously been the purview of a single agency, and the specific inclusion of a particular brand of bureaucratic actor-the career litigator.

Litigation can also prompt policy change in an effort to head off judicial interference. ${ }^{145}$ In addition to refining its legal arguments in anticipation of litigation, the government sometimes takes on forward-looking policy change rather than concede backward-looking legal obligations as a means of presenting the best possible face in court and staving off a potential adverse judgment. ${ }^{146}$ In other words, rather than concede that, for example, the government is obligated to apply specific treaty provisions to military detainees, the executive might choose instead to simply extend a heightened level of treatment as a matter of discretion, in an attempt to circumvent a judicial ruling on the matter. ${ }^{147}$ Finally, litigation can also entail a loss in court that may dramatically change the executive's position.

Nevertheless, in an area of considerable deference to executive positions, the most significant effect of the litigation catalyst is the shifting of internal power toward DOJ litigators, and the pressures it imposes on executive actors to defend past action and to preserve the greatest possible flexibility for the President. Defensive litigation is one of the most significant interpretation catalysts triggering executive legal decisionmaking, and is an instinctive go-to means of challenging executive action. Yet litigation-and, in particular, defensive litigation in the lower courts, where the government's arguments first take shape -triggers a process that is almost diametrically opposed to effecting

145. See generally Ashley Deeks, The Observer Effect: National Security Litigation, Executive Policy Changes, and Judicial Deference, 82 FoRDHAM L. REV. (forthcoming 2013) (arguing that judicial involvement can prompt executive branch national security policy changes even beyond the limited cases in which the executive actually loses).

146. Id.

147. It is impossible to know all of the reasons behind policy changes taken by the executive, but there are multiple examples of major policy initiatives or decisions announced in the midst of potentially momentous litigation, including revised procedures for detention at Bagram in the midst of post-Boumediene litigation addressing whether the writ of habeas corpus would run there, e.g., Al Maqaleh v. Gates, 605 F.3d 84, 96 n.4 (D.C. Cir. 2010) (noting the executive's change in procedures "being implemented only now when the case is before the Court of Appeals," and choosing not to rely on them in deciding the case); new administrative procedures for detainees at Guantanamo in the face of intense litigation pressure from habeas cases winding through the courts, SUBCOMM. ON OVERSIGHT AND INVESTIGATIONS OF THE COMM. ON ARMED SERVICES, HOUSE ARMED SERVICES COMMITTEE $\begin{array}{llll}\text { REPORT, LEAVING } & \text { GUANTANAMO } & 54 & (2012) \text {, }\end{array}$ http://armedservices.house.gov/index.cfm/files/serve?File id=dd0b4c6e-528e-4138-9755-86bae92el cdb (quoting former Navy Secretary and then-Deputy Secretary of Defense Gordon England as telling the House Armed Services Committee that the Department wanted to "get ahead of the curve" and "foreclose th[e] possibility" of court-ordered releases based on procedural technicalities by addressing the matter themselves); and decisions to transfer individual detainees out of military detention, made in light of litigation risks, Final Report: Guantánamo Review Task Force, DEP'T OF JUSTICE ET AL. 8 (Jan. $22,2010) \mathrm{http}: / \mathrm{www}$.justice.gov/ag/guantanamo-review-final-report.pdf (explaining that the evaluation to ensure lawfulness of a detainee's continued detention took into account "the government's case for defending the detention in any habeas litigation"). 
progressive change in legal policy. It is driven by tight deadlines that do not generally permit comprehensive collaboration or deliberation; handled predominantly by career litigators without significant authority or institutional incentive to promote additional constraints on executive authority; and shaped by its inherently defensive posture. Thus, in areas of significant deference from courts, such as national security and international law, defensive litigation is intrinsically ill-suited to advancing greater legal constraints on the executive. To the contrary, defensive litigation encourages the executive to assert a generous view of its legal authority, which-outside of those rare government losses-the process of litigation will only entrench.

\section{B. The Treaty Body Reporting Catalyst}

Unlike litigation, the U.S. government's interaction with international bodies over its international law obligations is in many ways a much less public, less understood process. Yet this interaction regularly triggers questions about the U.S. position on interpretation of treaty provisions that bind the government, which government lawyers are called upon to address.

The United States has signed and ratified several human rights treaties that contain periodic reporting requirements, including the International Covenant on Civil and Political Rights (ICCPR) and the Convention Against Torture and Other Cruel, Inhuman or Degrading Treatment or Punishment (CAT). These instruments establish, respectively, the Human Rights Committee and the Committee against Torture (CAT Committee) ${ }^{148}$ Among these committees' duties are the receipt and consideration of periodic reports from the states parties to the treaties on measures they have taken to implement their treaty obligations. ${ }^{149}$ In practice, treaty body reporting is an elaborate process and involves a fair degree of back and forth with the committees. Per the CAT optional reporting procedure, which has been adopted by the United States, and will govern U.S. reports going forward, the process now begins with a list of questions asked by the CAT Committee, to which the states respond. ${ }^{150}$ Under the original CAT procedure, the state first submitted its report, and then defended the report through written and oral answers to committee questions. ${ }^{151}$ Both processes culminated in a set of Committee observations and recommendations for the state party's consideration.

148. International Covenant on Civil and Political Rights, Dec. 16, 1966, S. EXEC. Doc. E, 95 2, (1978), 999 U.N.T.S. 171 [hereinafter ICCPR]; Convention Against Torture and Other Cruel, Inhuman or Degrading Treatment or Punishment, Dec. 10, 1984, S. TREATY DOC. No. 100-20, (1988), 1465 U.N.T.S. 85 [hereinafter CAT].

149. See ICCPR, supra note 148 , art. 40 (obligating the states parties "to submit reports on the measures they have adopted which give effect to the rights recognized herein and on the progress made in the enjoyment of those rights"); CAT, supra note 148, art. 19(1) (obligating the state parties to submit "reports on the measures they have taken to give effect to their undertakings under this Convention").

150. Convention Against Torture and Other Cruel, Inhuman or Degrading Treatment or Punishment, Oct. 31-Nov. 25, 2011, Status of the Optional Reporting Procedure of the Committee Against Torture and Proposals for Its Revision, U.N. Doc. CAT/C/47/2 (Sept. 27, 2011).

151. CAT, supra note 148 , art. 19 
There exists in the scholarship a vibrant debate regarding the proper role of treaty bodies in advancing or interpreting international law through expression of their own views on legal interpretation and compliance. ${ }^{152}$ This Article does not wade into that debate directly but rather explores the processes these reporting commitments may trigger within a particular state, here the U.S. executive branch, and how those processes affect the government's legal interpretations, thus contributing in a more circuitous manner to the evolution of international law. The internal U.S. executive processes that flow from these reporting requirements contrast sharply with the decisionmaking processes that emerge from other catalysts discussed herein. In particular, the treaty body catalyst both provides an opportunity for and encourages decisionmaking in a forum predisposed toward interagency collaboration, human rights advancement, and prioritization of international law.

\section{Who Has the Pen?}

U.S. engagement with other countries and international bodies over its international law obligations is handled primarily by the State Department Office of the Legal Adviser (L), an office of approximately 175 career attorneys ${ }^{153}$ with only one political appointee, the Legal Adviser, who typically chooses one or two special assistants but has little ability to change the political composition of the office. ${ }^{154} \mathrm{~L}$ attorneys serve, inter alia, as agency general counsel, as general international law experts and thus advisers to the rest of the executive, and as essential representatives on U.S. delegations that negotiate treaties and other agreements internationally. ${ }^{155}$

L plays a primary role in drafting and coordinating the U.S. reports to the treaty body committees and responses to the committees' follow-up questions, and organizes the delegation of officials from the interagency who will attend the committee hearings. Within L, the officials tasked with driving the process are career attorneys housed within the Human Rights division (L/HRR). ${ }^{156}$ This division is tasked generally with providing the Department with legal guidance on human rights and refugee law and representing the U.S. government in the

152. See, e.g., José Alvarez, INTERNaTIONAL ORGanizations aS LAW-MAKERS 6 (2005); Kerstin Mechlem, Treaty Bodies and the Interpretation of Human Rights, 42 VAND. J. TRANSNAT'L L. 905 (2009) (discussing ongoing debate about the role of treaty bodies); Anthea Roberts \& Sandesh Sivakumaran, Lawmaking by Nonstate Actors: Engaging Armed Groups in the Creation of International Humanilarian Law, 37 YALE J. INT'L L. 107, 116-17 (2011) (calling it "increasingly well-accepted" that "bodies such as the ILC and Human Rights Committee influence the development and interpretation of international law"); see also MALCOLM N. SHAW, INTERNATIONAL LAW 923 n.102 (2008) (noting disagreement between the U.N. Human Rights Committee and the U.S. and U.K. governments over the Committee's role in recognition of treaty reservations).

153. Practicing Law in the Office of the Legal Adviser, U.S. DEP'T OF STATE, http://www.state .gov/s/1/3190.htm (last visited Mar. 5, 2013).

154. Rao, supra note 15 , at 233.

155. See, e.g., Harold Hongju Koh, The State Department Legal Adviser's Office: Eight Decades in Peace and War, 100 GEO. L.J. 1747, 1758 (2012).

156. Practicing Law in the Office of the Legal Adviser, supra note 153. 
international arena on these matters. ${ }^{157}$ Attorneys in L/HRR not only play a coordinating role with their counterparts throughout the executive branch; they also interact regularly with counterparts in other countries and NGOs, and sit on delegations to U.N. and other human rights bodies where they negotiate resolutions and painstakingly navigate difficult legal human rights issues. ${ }^{158}$ These attorneys, tasked with drafting and coordinating the treaty reports, thus bring to that process an intense awareness of the legal positions of other countries and their points of tension or sympathy with U.S. positions. Having honed their negotiation skills through the process of forcefully advocating on behalf of the U.S. government with foreign officials, they are also in a position to understand the relative weaknesses of particular U.S. positions, and where those positions could stand to be moved.

In preparing new reports to the relevant treaty bodies, $\mathrm{L}$ attorneys typically first prepare a draft based largely on prior reports, with attempts to address the recommendations and comments from the Committee during the last reporting round. ${ }^{159}$ In addition, significant pieces of treaty reports are often farmed out to the critical agencies with the greatest substantive expertise and stake in the product so that they may take a first cut. Thus, for example, attorneys and policy players at the Department of Defense are heavily involved in drafting and reviewing treaty report language addressing detainee or other military matters. The Department of Homeland Security might take the lead on certain immigration questions, or DOJ on questions regarding prisoners' rights. In such cases L lawyers will work collaboratively with other agencies to craft language and keep the process moving.

\section{Mechanisms for Coordination and Decision}

Although as a matter of practice L has historically taken the lead in coordinating and crafting the U.S. response to its treaty body reporting obligations, formal authority for this process has changed hands to some extent over the years, and ultimate decisionmaking authority on the positions the U.S. government takes in this context is less clear than it is with litigation. Formal coordination authority has been vested in the NSC, through various working groups and committees; yet in practice, the enormous task of drafting, coordinating, and shepherding treaty body reports through the interagency, transmitting them to the committee, and then coordinating the delegation to address the committee's concerns has primarily fallen to $\mathrm{L}$. This process has included significant engagement from agencies that hold major expertise or investment in the substance of the reports.

Both the Clinton and Bush Administrations attempted to consolidate the treaty reporting process under formal committees run out of the NSC. In 1998,

157. Id.

158. Id.; SCHARF \& WILLIAMS, supra note 12, at xix; Koh, supra note 155, at 1773.

159. Going forward, reports will also be responsive to the Committee's list of issues, per the new optional reporting process. See supra text accompanying note 150. 
in an effort to aid implementation of various aspects of the human rights treaties ratified over the course of the prior decade, including the treaty body reporting requirements, President Clinton issued Executive Order 13,107..$^{160}$ This order created an "Interagency Working Group on Human Rights Treaties" (IWAG), chaired by the National Security Adviser and comprised of "appropriate policy and legal representatives at the Assistant Secretary level from the Department of State, the Department of Justice, the Department of Labor, the Department of Defense, the Joint Chiefs of Staff, and other agencies as the chair deems appropriate," though "[ $t]$ he principal members may designate alternates to attend meetings in their stead." 161 Among the principal functions of the IAWG was "coordinating the preparation of reports that are to be submitted by the United States in fulfillment of treaty obligations." 162

Despite the IAWG's broad mandate to coordinate treaty body reporting, the U.S. government's first report to the CAT Committee was prepared and coordinated by the State Department, with "extensive assistance" from other agencies. ${ }^{163}$ In any event, the IAWG's run was short-lived. Shortly after taking office President Bush abolished and replaced the existing working groups, transferring the IAWG duties to a new NSC Policy Coordination Committee (PCC) on Democracy, Human Rights, and International Operations. ${ }^{164}$ This new PCC never got off the ground. ${ }^{165}$ Instead, L staff engaged to coordinate and draft the now-overdue reports, with significant assistance from NSC, who agreed to prioritize the reports and chair the interagency meetings, thus ensuring greater interagency participation. ${ }^{166}$

Since then, $\mathrm{L}$ has continued to play the primary role in coordinating U.S. responses to the treaty bodies, with the assistance of NSC staff (NSS) and other officials within the State Department and throughout the interagency. ${ }^{167}$ This may be due as much to manpower-NSS is notoriously short-staffed-as to L's expertise and familiarity with the treaty bodies. L attorneys take on the lion's share of drafting and revising, and coordinating with the interagency, with assistance from NSS, especially with respect to promoting interagency participation. ${ }^{168}$ The State-led process has faced criticism from some that, as an

160. Exec. Order No. 13,107, 63 Fed. Reg. 68,991 (Dec. 10, 1998).

161. Id. at 68,992 .

162. Id. $\| 4$ (b)(ii).

163. Convention Against Torture and Other Cruel, Inhuman or Degrading Treatment or Punishment, Consideration of Reports Submitted by States Parties Under Article 19 of the Convention, U.N. Doc. CAT/C/28/Add.5, at 4 (Feb. 9, 2000).

164. Memorandum from President George W. Bush, National Security Presidential Directive, (Feb. 13, 2001), available at http://www.fas.org/irp/offdocs/nspd/nspd-1.htm.

165. Tara Melish, From Paradox to Subsidiarity: The United States and Human Rights Treaty Bodies, 34 YALE J. INT'L L. 389, 402 (2008).

166. Id.; Interview with Sandra Hodgkinson, Former Director for Intemational Justice, Nat'l Sec. Council; Deputy to Ambassador-at-Large for War Crimes Issues, U.S. Dep't of State; Deputy Assistant Sec'y of Def. for Detainee Affairs, U.S. Dep't of Def. (Jan. 19, 2012).

167. Melish, supra note 165, at 402; Catherine Powell, Human Rights at Home: A Domestic Policy Blueprint for the New Administration, AM. CONST. SOC'Y FOR L. \& POL'Y 7, 13, (Oct. 2008), http://www.acslaw.org/files/Powell\%20full\%20combined.pdf.

168. Powell, supra note 167 , at 7 . 
agency focused on foreign rather than domestic policy, State is unlikely to have sufficient influence on domestic actions, which are relevant to much of the human rights implementation focus of the committees. ${ }^{169}$ Nevertheless, under the practice of at least the last two Administrations, the State-led reporting process has involved intense coordination and vetting between relevant agencies, as well as outreach to and consideration of views from local governments and representatives from civil society. ${ }^{170}$ To date, U.S. engagement and interagency coordination in the treaty body reporting process has been considerable. Despite lags in reporting, the U.S. government has crafted extensive reports and has staffed delegations to the committees with high-level officials from throughout the executive branch. ${ }^{171}$

But the agency with the pen does not necessarily have the final say on positions taken by the executive. In addition to the agencies that are asked to draft relevant sections of the report, others are asked to comment on or clear sections that are relevant to them. While $\mathrm{L}$ coordinates the larger project, to the extent there is interagency disagreement over a position that cannot be resolved through this informal process, NSS will call an interagency meeting to resolve the matter. ${ }^{172}$ At such meetings a premium is placed on reaching agreement. There is an understanding on the part of those preparing the reports that buy-in from other executive components is essential to keep the process working and to ensure the most comprehensive and accurate response. Unlike in litigation, in which an individual attorney must face on-the-spot questioning from a judge or panel, even the questions asked by the treaty committees are generally provided in advance, permitting written responses to be prepared and fully vetted. ${ }^{173}$ The exigencies and pressures that in the litigation context may require vesting decisionmaking authority in the hand holding the pen are much less intense in the treaty body reporting process. The holder of the pen still plays an important role, for the reasons discussed in Subsection III.A.1, but in the treatyreporting context, collaboration and consensus are both possible and, in fact, are considered paramount.

\section{Contextual Pressures and Utility of the Treaty Body Reporting Catalyst}

Unlike in litigation, in which forces align to pressure the executive into a defensive position regarding its obligations and preserve maximum flexibility, the treaty-reporting context creates pressure and opportunity for the

169. Id.

170. See, e.g., Fourth Periodic Report of the United States of America to the United Nations Committee on Human Rights Concerning the International Covenant on Civil and Political Rights, U.S. DEP'T OF STATE I 4 (Dec. 30, 2011), http://www.state.gov/j/drl/rls/179781.htm [hereinafter ICCPR Report].

171. See, e.g., Melish, supra note 165, at 406 ("Although the United States-not unlike many other nations - has frequently been late in submitting its reports, it has actively engaged with the supervisory treaty bodies in the periodic reporting process ....").

172. See supra note $\mathbf{1 6 6 .}$

173. See infra Part IV. 
Administration to reach a position in a forum that prioritizes international law and human rights to the extent possible. ${ }^{174}$ The process reminds the U.S. government of its legal obligations and promotes compliance with respect to policies and enforcement, and can pressure U.S. officials toward interpretations of legal commitments that are more in line with the understanding of the committee and the international community. ${ }^{175}$

U.S. officials tend to view the reports themselves and subsequent meetings with the committees as opportunities to highlight positive U.S. policies and practice. ${ }^{176}$ There is thus often a desire on the part of such officials to have certain "deliverables"-positive updates on policy, implementation, or even an evolving legal interpretation-that they can bring to the committee hearings. ${ }^{177}$ Moreover, advocates for change within the executive can use the process instrumentally to promote these developments. ${ }^{178}$

Regular reporting on states' interpretation of treaties in addition to their implementation can be critical because new events may raise questions that states did not necessarily grapple with at the time of negotiation or ratification. Modern circumstances may call for updating the state's understanding of its obligations under a given treaty and assessing how it applies to novel situations or contexts. The evolving U.S. understanding of domestic and international law as applicable to its detention operations at Guantánamo Bay is one such example. ${ }^{179}$ In the early years after $9 / 11$, the executive's positions on its legal constraints at Guantánamo included the views that neither the writ of habeas corpus nor the provisions of various human rights treaties extended to its detainee operations there. ${ }^{180}$ Yet over the course of a decade, these views shifted in both dramatic and nuanced ways, due to a mix of both external factors and to the executive branch's own changed positions. ${ }^{181}$ Such shifts can critically affect a state's interpretation of and compliance with treaty obligations, which can raise questions in multiple contexts, including but by no means limited to the reporting process. Thus, whether or not the U.S. position

174. This does not ensure that all positions taken in the treaty-reporting context will align perfectly with a progressive human rights agenda - for example, the U.S. government has for years clashed with the U.N. Human Rights Committee over the extraterritorial reach of some of its treaty obligations-but the treaty-reporting catalyst is more likely to prompt decisionmaking along human rights lines than other catalysts. See, e.g., John Bellinger, Administration Submits ICCPR Report, Punts on Extraterritorial Application, LAWFARE (Jan. 19, 2012, 10:46 AM), http://www.lawfareblog.com /2012/01/administration-submits-iccpr-report-punts-on-extraterritorial-application.

175. See, e.g., Press Release, U.S. Dep't of State, The United States' Oral Response to the Questions Asked by the Committee Against Torture (May 8, 2006), www.state.gov/j/drl/rls/68562.htm [hereinafter CAT Oral Response] (calling U.S. engagement with the CAT committee over the treaty reporting process a "vital instrument in th[e] effort" to "meet[] our domestic and international obligations to combat torture").

176. Interview with Sandra Hodgkinson, supra note 166.

177. Id.

178. Id.

179. See infra Part IV.

180. See infra notes 210-214 and accompanying text.

181. See, e.g., Boumediene v. Bush, 553 U.S. 723, 793, (2008) (extending the writ of habeas corpus to aliens detained at Guantánamo); infra Part IV (exploring the United States' evolving position on the prohibition on the use of statements derived from torture, under the Convention Against Torture). 
that ultimately arises out of a treaty reporting process conforms to the exact views of the committee, the process encourages U.S. officials to come together to coordinate and crystallize a position in an environment and through a process geared toward promotion of the U.S. record on human rights. ${ }^{182}$ As one recent U.S. report states, the U.S. government views the treaty reporting process as "an important tool" in the development of its human rights practices and performance, and an "opportunity to engage in a process of stock-taking and self-examination." 183

To be sure, the effect of treaty body reporting on legal change should not be overstated. As with other areas of executive branch legal interpretation, new interpretations of law occur quite rarely. Government lawyers, wherever they are housed throughout the executive, are inherently conservative in conceding legal constraints. Moreover, as in other contexts, precedent plays an enormous role in the treaty body reporting process, and great emphasis is placed on continuity in U.S. positions. ${ }^{184}$ The focus on consensus means there is a high bar for changing the government's position. If there is no consensus on taking a new position, the status quo-or vagueness - is always a potential fallback.

Nevertheless, the executive does sometimes change course. And unlike litigation, the treaty-body reporting catalyst brings together the distinctive decisionmaking elements that are best suited to promoting progressive change in both law and policy. Where potential "policy windows" 185 exist-in areas where evolving circumstances call for innovative reasoning, or in areas of debate within the executive where potential for change may hinge on contextual pressures, involvement of particular players, or simply getting the issue onto the agenda - the treaty-body reporting process provides a forum for decisionmaking that permits long-term contemplation and coordination, heavy input from "expert" agencies, room for interaction between political and career players, and space for legal policy development in a context that prioritizes international law compliance, the promotion of human rights, and engagement with the international community.

\section{Speechmaking as Interpretation Catalyst}

The prior two sections discussed interpretation catalysts that are primarily driven by external factors. But internally-triggered events can also operate as compelling interpretation catalysts. Decisions to take a particular action or implement a policy can fall under this category, as can determinations to make a speech to express publicly the Administration's views on a given matter. Speechmaking is a particularly interesting interpretation catalyst as it can be provoked by a combination of internal and external factors. And as a somewhat more pliable tool than those that are more formally responsible to external

182. See, e.g., ICCPR Report, supra note $170, \mathbb{2} 2$.

183. Id.

184. See infra Part IV.

185. See, e.g., KINGDON, supra note 27. 
bodies like courts or treaty-reporting bodies, it can be employed strategically by officials within the government seeking to shape the decisionmaking process. ${ }^{186}$

The decision to give a speech on a matter of international law and national security is rarely a decision made casually or unilaterally by the particular speechmaker herself, and the impetus to do so can be driven by a range of internal and external factors. There may exist external pressure, such as calls upon the executive-by media, Congress, or others-to explain its position in a given area. For example, there have been widespread calls in recent years for greater clarity from the Obama Administration regarding its legal position on targeting killing, which have resulted in a number of speeches by government officials explaining the policy and legal framework in ever greater detail. ${ }^{187}$ Pressure to make public a set of legal views may also come from within the Administration, from actors who wish to explain the government's position in an effort to mollify criticism about either the substantive decisions or the lack of transparency about the decisionmaking process. ${ }^{188}$

Speechmaking may simply reveal to the public the pre-existing legal rationale for executive policies or programs; it can also be an action-forcing mechanism driving the executive to crystallize and finally bind itself to a position on a matter. ${ }^{189}$ As with other interpretation catalysts, speechmaking can shape the parameters of a particular decisional moment-its timing and the context in which the decision is made - and it can create greater leverage for the speechmaker and related officials at the decisionmaking table. There are numerous other means officials employ to create leverage, including strategic leaking and resignation threats, both of which are unilateral means to influence decisionmaking. Speechmaking is distinct in that it actually creates a different decisionmaking forum - the process of drafting and coordinating a position and language for the speech itself in a very specific context—and thus influences

186. A distinctive feature of the speechmaking catalyst is that the President himself can and does employ it to great effect. There are many reasons a President himself chooses to give a speech, some of which are similar to those explored in this section for individual officials. Presidential speechmaking, as with speechmaking by other officials, can act as an action-forcing event or drive internal process to force agreement on a matter. The President may also use speechmaking to clarify his own position publicly and bind those who must implement his decisions. See, e.g., Remarks on National Security, 2009 DAILY COMP. PRES. DOC. 1 (May 21, 2009).

187. See, e.g., Kenneth Anderson, Readings: The Canonical National Security Law Speeches of Obama Administration Senior Officials and General Counsels, LAWFARE (June 11, 2012, 3:37 PM), http://www.lawfareblog.com/2012/08/readings-the-canonical-national-security-law-speeches-of-obama -administration-senior-officials-and-general-counsels.

188. See, e.g., Benjamin Wittes, Dan Klaidman on Stephen Preston's Harvard Speech, LAWFARE (Apr. 16, 2012, 11:22 PM), http://www.lawfareblog.com/2012/04/dan-klaidman-on-stephen -prestons-harvard-speech (suggesting that Stephen Preston and Harold Koh had been among those within the executive pushing for greater transparency regarding the policy on targeted killings).

189. See, e.g., RICE, supra note 74, at $499-500$ (explaining that, upon finding herself on her way to a NATO meeting in the midst of a press flurry about CIA black sites, she was able to push the NSC, other Principals, and the President to allow her to make a statement that both "hinted that the CIA was indeed operating facilities overseas," and announced if not a legal interpretation regarding the extraterritoriality of certain U.S. human rights obligations, at least a statement of legal policy leaning toward that position). 
substance by transforming the process, shaping the contextual pressures, and ensuring specific coordination.

\section{Who Has the Pen?}

Unlike litigation and treaty-reporting, which are ongoing processes that may cross administrations and can be channeled to some degree by the career bureaucracy, speechmaking is inherently top-down, involving high-level, politically-appointed officials. Career officials may be involved but just as often it may be the political assistants surrounding the speechmaker who assist substantively in the process.

Which official volunteers or is asked to take on a speech is critical because speechmaking-whether intended for this purpose or not-gives that official, and those working for her, the pen on the public representation of an issue, and it can thus be an opportunity for an official to gain inclusion in a matter to which she might otherwise not have access. ${ }^{190}$ Speechmaking may grant to an official otherwise out of the loop not only a seat at the decisionmaking table, but also a place of significant influence. ${ }^{191}$ Once a key administration official is slated to give a speech, her views cannot be disregarded. She cannot be left out of the speechwriting room. The words will be hers to say or to refuse to say, and this provides some degree of leverage over the position and over what will be made public. Going forward, these statements are generally taken to be the considered views of the U.S. government, and cannot easily be reversed. ${ }^{192}$ Indeed, they are likely to be referred to in other contexts where U.S. officials are required to explain the government's position. ${ }^{193}$ Of course, it is unlikely that speechmaking could be used to draw into the conversation an official who has no relevance to a particular area, but it may be effective in pulling up a critical chair to the table for an individual with both expertise and a structural connection to the matter at hand.

The elevated seat at the table does not come cheaply for the speechmaker. The speechmaking-as-strategy process operates as a two-way street. By presenting the U.S. views on a topic in a public forum, the speechmaking official is sanctioning those views and signing on quite publicly to the U.S. position, in a way that will be difficult, if not impossible, to walk away from at a later date. ${ }^{194}$ It is this legitimizing effect that the speechmaker often brings to the table in exchange for greater influence in the cultivation of the views that

190. See, e.g., CHAYES, supra note 14 , at 31 .

191. See infra text accompanying notes 198-200.

192. This Article focuses not on statements made without coordination or otherwise ultra-vires, but rather on the properly-articulated and vetted positions of the executive branch.

193. See, e.g., Government's Memorandum of Law in Opposition to Plaintiffs' Motion for a Preliminary Injunction at 6, Hedges v. Obama, 890 F. Supp. 2d 424 (S.D.N.Y. 2012) (No. 1:12-cv00331-KBF) (quoting DOD General Counsel Johnson's speech for the U.S. position on the scope of the AUMF as it applies to "associated forces" of al-Qaeda and the Taliban).

194. Id. 
will be presented. ${ }^{195}$ This phenomenon may be most palpable in areas where an official may have greater legitimacy with a particular population that the Administration hopes to sway in large part because she is seen-rightly or wrongly - as potentially holding views in tension with the Administration's policies in that area. In such cases, the official both may desire greater leverage internally in order to influence decisionmaking, and may have an important legitimizing power in sanctioning the resulting views. Thus, both the speechmaking official and others in the Administration have something to gain in finding a compromise that permits the official to give a public speech on the matter.

By way of example, State Department Legal Advisers-and even Secretaries of State ${ }^{196}$-have often been deployed to explain the U.S. government's legal position on matters affecting international law and national security, to both international and domestic audiences. Harold Koh's 2010 speech at the American Society of International Law, in which he discussed the Obama Administration's views toward targeting and detention in the conflict with al Qaeda ${ }^{197}$ received enormous public attention in part because of his stature as a leading human rights advocate. Thus, Koh's willingness to support the Administration's legal position was a boon to the Administration in facing criticism from the human rights community, and Koh presumably may have gained greater influence than he might otherwise have had in crafting the public statement of the Administration's position on wartime targeting and detention. Previously, under the Bush Administration, Legal Adviser John Bellinger gave a number of speeches explaining the U.S. government's understanding of its legal obligations under international law in the conflict with al Qaeda. ${ }^{198} \mathrm{He}$ publicly presented, explained, and defended the executive's positions-and in so doing worked toward trying to legitimize them-despite the fact that, as it is now widely known, he had had many disagreements with other Bush officials over many of the prevailing policies throughout the early years of the

195. See infra notes $197-200$ and accompanying text.

196. See supra note 189.

197. Harold Koh, Legal Adviser, U.S. Dep't of State, Address at the Annual Meeting of the American Society of International Law: The Obama Administration and International Law (Mar. 25, 2010), http://www.state.gov/s/l/releases/remarks/139119.htm.

198. See, e.g., John B. Bellinger, Legal Adviser, U.S. Dep't of State, Address at the London School of Economics: Legal Issues in the War on Terrorism (Oct. 31, 2006), http://www.state.gov $/ \mathrm{s} / 1 / 2006 / 98861 \mathrm{htm}$ (explaining the USG's position on the law applicable to the conflict with al Qaeda); John B. Bellinger, Legal Adviser, U.S. Dep't of State, Keynote Address at the International Law Weekend of the American Branch of the International Law Association: Reflections on Four Years as Legal Adviser (Oct. 17, 2008) http://2001-2009.state.gov/s/1/rls/11 1049.htm (explaining the importance of L's role in "international legal diplomacy," including in the drafting of speeches, articles and blog postings, in order to try "to meet our critics on these issues and to narrow the points of disagreement ... even in instances when [he] had urged a different policy"). State Department Legal Advisers have long explained U.S. positions on legal authority in matters of national security. See, e.g., Abraham D. Sofaer, Terrorism, the Law, and the National Defense, 126 MIL. L. REV. 89 (1989) (discussing, inter alia, international law regarding the use of force against terrorist groups); William $\mathrm{H}$. Taft, IV, The Law of Armed Conflict After 9/11: Some Salient Features, 28 YALE J. INT'L L. 319, 322 (2003) (discussing, inter alia, minimum law of war standards that apply to "unprivileged belligerents" in armed conflict). 
Administration. ${ }^{199}$ Considering the willingness of those other officials to cut the State Department out of the decisionmaking loop, as revealed years later by Legal Adviser Taft and others, ${ }^{200}$ the ability to act as speechmaker and public face of the Administration's views of its authority likely elevated L's role in addressing these matters to some degree. At a bare minimum it ensured the State Department had a seat at the position-drafting table, which it might otherwise not have had.

\section{Mechanisms for Coordination and Decision}

While the speechmaker and her office may hold the pen, this does not necessarily result in ultimate decisionmaking authority over what is said or revealed publicly. Instead, coordination and consensus are often critical. Unlike with other mechanisms discussed, speechmaking does not have a necessary externally-driven timetable or set of questions that must be answered. Even once a speech is announced, it can always take a diluted or more aggressive form depending on what can get cleared in the time officials have to prepare. And the lack of an external decisional body means that the executive is free to shape the line of argument entirely. This lack of an external focus permits a greater premium on consensus and buy-in. The lessened pressure to respond to particular questions means that the executive can promulgate and provide only those answers that officials are prepared to give. Though internal assumptions and norms about coordination and clearance are mutable, the greater the coordination in vetting the speech ex ante, the greater the likelihood the speech will create internal precedent going forward. This is true in part because, as will be explained below, cleared language tends to be recycled in later written product addressing the same issues.

In addition, because speechmaking inherently tends to implicate highlevel public officials, coordination of the government's position will necessarily involve the high-level speechmaker and will likely be vetted among colleagues of an equal stature to that official throughout the interagency. And unlike other catalysts, speechmaking tends to implicate a host of other interested players such as press and communications officials who bring unique perspectives and pressures to the table.

\section{Contextual Pressures and Utility of the Speechmaking Catalyst}

As a catalyst over which executive officials exercise significant control, speechmaking is explicitly used to answer criticism, explain a position, or highlight positive policies-in a highly public manner-when doing so is seen as useful to an official or the executive more broadly. Thus it encourages the promulgation of positions that (1) can be issued publicly and (2) will satisfy a

199. See, e.g., Barton Gellman, ANGler: The Cheney Vice Presidency (2008).

200. See, e.g., id.; SCHARF \& WILLIAMS, supra note 12. 
given audience, on (3) a timetable that serves the executive or a particular official.

With the speechmaking catalyst the audience may be multifaceted; thus a speechmaker may seek, for example, simultaneously to reassure a civil liberties-oriented listener of the reasonable constraints on the President's authority to use military force to target particular groups or individuals, while assuring a security-oriented listener that the executive branch is aggressively pursuing security threats. ${ }^{201}$ It is also an audience over which the official has some control, by for example choosing to present her speech at a particular forum-although in the internet age, that control is rarely perfect-and she may exercise that control as a way of seeking to influence the message.

Speechmaking provides an opportunity for laying out new policy or legal views in a context in which particular officials can manage and to some degree manipulate the timetable. Speechmaking often builds on positions that are either already formed or are in the process of forming internally within the executive, but an upcoming speech-and thus the decision to give it-can bring matters to a head and shape the pressures affecting the decision.

Finally, speechmaking can further entrench a position first by creating a vetted written document, and then through its public disclosure. As with positions taken in other contexts, the views expressed by U.S. officials in speeches are generally taken to be the coordinated views of the U.S. government as a whole, and are difficult (and should require explanation) to later reverse. ${ }^{202}$ Unlike litigation and the treaty-body reporting process, speechmaking is not specifically directed at a formal body that will hold the U.S. government to its prior positions and demand explanation for change; nevertheless, the media and voting public will likely expect such explanation, and speeches are generally a more public medium than briefs or treaty reports. ${ }^{203}$ And as a practical matter, the vetting and clearing of the executive's position on an issue, in particular, an issue of legal interpretation, can be so difficult and time-consuming that once a speech or other statement is cleared, it is repeatedly recycled and becomes the go-to source for all talking points, reports, briefs or anything that requires explaining the government's position

201. See, e.g., Jeh Johnson, Gen. Counsel, U.S. Dep't of Def., Dean's Lecture at Yale Law School: National Security Law, Lawyers and Lawyering in the Obama Administration (Feb. 22, 2012), available at http://www.lawfareblog.com/2012/02/jeh-johnson-speech-at-yale-law-school (outlining an expansive geographic scope of the conflict while dismissing a "Global War on Terror").

202. The extent to which various means of presenting the U.S. government's legal views are considered binding by either the executive or external actors is complex and worthy of future exploration. Trevor Morrison has examined this concept in the OLC context, and with Curtis Bradley explores the precedential value of executive action in relation to separation of powers concerns. See Curtis A. Bradley \& Trevor W. Morrison, Historical Gloss and the Separation of Powers, 126 HARV. L. REV. 411 (2012); Morrison, supra note 25.

203. Indeed, courts have taken note of executive speechmaking. See Jan Crawford, Appeals Court Fires Back at Obama's Comments on Health Care Case, CBS NEWS (Apr. 4, 2012), http://www.cbsnews.com/8301-504564_162-57408827-504564/appeals-court-fires-back-at-obamas-comments -on-health-care-case. 
on that matter, further extending-and prolonging-the effect of the initial statement. ${ }^{204}$

Unlike the litigation and treaty body catalysts, speechmaking does not tend to provide an opportunity for granularity of legal positions. The purpose is generally to explain the executive's views or policy at a level comprehensible to the public, including non-lawyers and non-experts. But like these other catalysts, it would be rare for speechmaking to force the executive to take a position that all or most internal officials would otherwise aggressively avoid. In fact, speechmaking does not necessarily tend in a given substantive direction other than toward greater transparency. Speechmaking can be defensive when it is employed to explain prior action; it can emphasize human rights or international law when used to curry favor with an international audience.

As a procedural tool, however, speechmaking has a clear influence within the executive. Speechmaking's most significant procedural effect is its necessary inclusion of a particular high-level official into the decisionmaking process. The speechmaker will also often control the nature of the audience to whom she speaks, and thus can influence the contextual pressures surrounding the speech. Thus the speechmaker can drive a decisionmaking process around a particular timetable, shape the players involved, influence the contextual pressures, ensure the durability of the position expressed, and secure her own position-of-honor at the decisionmaking table. Speechmaking may thus be one of the most instrumental catalysts available for high-level executive officials.

\section{COMParing Catalysts, a CaSe Study: THe 2005-2006 Report to the COMMITTEE AGAINST TORTURE}

Much legal decisionmaking - in particular the decision to change course from a prior legal position or to announce a new one-involves mixed questions of law and policy. ${ }^{205}$ This is especially so in areas such as international law and national security where there often exists some ambiguity, evolving norms, or a range of views on difficult questions. Such decisionmaking often involves not only guidance regarding the available reasonable interpretations of the law, but the policy decision to choose one interpretation over another, to change course, or to announce a position rather than preserve flexibility, which may be based not only on that legal guidance but on a host of other factors including morality, public opinion, or the positions of other states.

Momentous legal change is difficult and requires a perfect storm of contextual and procedural elements in order to succeed in challenging the status quo. ${ }^{206}$ It requires the participation and investment of decisionmakers with sufficiently high-level authority and political will to commit to new decisions that will bind the government; a process that both creates pressure to act while

204. See supra notes 192-193 and accompanying text.

205. See, e.g., Koh, supra note 155.

206. See, e.g., KINGDON, supra note 27; Samuelson \& Zeckhauser, supra note 21 , at 8. 
permitting sufficient time for the potential alternatives to be discussed and consequences evaluated; and contextual pressures that are conducive to or even incentivize change. Interpretation catalysts play a significant role in shaping many if not all of these factors, and thus distinct catalysts trigger processes that are more or less suited for effecting legal policy change or for entrenching the status quo. Which catalyst triggers the ultimate decisionmaking process can thus be decisive in determining the resulting decision and can operate as a facilitator or roadblock to change. Yet which of these processes takes hold is often not a reasoned choice but relates instead to the force of a particular catalyst, or can even be as simple a matter as which interpretation catalyst occurs first.

This Part applies the theoretical framework discussed in previous sections to a concrete example, the U.S. reporting process to the Committee against Torture in 2005 to 2006 . The following case study highlights the effects of individual interpretation catalysts, in particular, the treaty body reporting catalyst and its contrast with the litigation catalyst, on the position of the U.S. government regarding the application of its obligations under the Convention Against Torture to wartime detainees.

In the spring of 2006 , in the midst of scandals over detainee abuse, reports of interagency antagonism over legal and policy decisions, setbacks in the courts over many wartime policies concerning detention and trial of detainees, and widespread criticism of the Administration's relationship with the international community and human rights bodies in particular, a high-level delegation of officials from several agencies throughout the Bush Administration traveled to Geneva to present and answer questions regarding the U.S. report to the U.N. Committee Against Torture.

Signed in 1988 and ratified in 1994, the CAT is one of the major human rights treaties to which the United States is a party. ${ }^{207}$ As a general matter, the CAT prohibits acts of torture or other cruel, inhuman, or degrading treatment or punishment (CIDT), and places requirements on states parties to prevent such acts and investigate allegations of abuse. ${ }^{208}$

Historically, there has been controversy between the U.S. government and other CAT parties over the scope of its application; U.S. officials have, over the years, repeatedly suggested limitations to the U.S. understanding of the CAT's substantive provisions and jurisdictional scope. At the time of ratification, the United States made several reservations and understandings, including to the definitions of both torture and CIDT, in part to ensure that U.S. obligations would be coterminous with existing obligations under the U.S. Constitution and other federal laws. ${ }^{209}$

207. See CAT, supra note 148 .

208. Id.

209. See CAT, supra note 148 (reservations and understandings of the United States upon ratification); Message from the President of the United States Transmitting the Convention Against Torture and Inhuman Treatment or Punishment, S. TREATY DOC. No. 100-20, at 15 (1988) [hereinafter 
With respect to its jurisdictional scope, U.S. officials historically have asserted both that particular provisions of the CAT do not apply extraterritorially, and that the Convention does not apply to situations of armed conflict, and by extension that it does not apply to detainee operations, including to the military detention facilities at Guantanamo. ${ }^{210}$ For example, during negotiations leading up to the Convention, a U.S. representative stated that the Convention "was never intended to apply to armed conflicts," suggesting concern that overlapping jurisdiction between the CAT and the Geneva Conventions "would undermine the objective of eradicating torture."211 In the early Bush years, the consistent position was that relevant CAT provisions did not apply to detainee operations or outside of the United States. $^{212}$ And in the context of domestic litigation in which the U.S. government was defending itself against allegations of detainee abuse at Guantánamo at the time of the CAT report, the government was aggressively fighting any extension of judicially enforceable rights to detainees at Guantánamo. $^{213}$ It therefore should have come as no surprise when, in its response to questions from the CAT Committee in 2006, the U.S. delegation confirmed the U.S. position that the law of armed conflict, and not the CAT, applied as "the lex specialis applicable to" "U.S. detention operations in Guantánamo, Afghanistan, and Iraq [because they] are part of ongoing armed conflicts." 214 One particular question, however, had not yet directly arisen in U.S. domestic litigation and was thus somewhat up for grabs at the time of the 2005-2006 treaty reporting process. Yet it was nevertheless an issue of pressing importance and great controversy. That issue was the admissibility in legal proceedings of statements derived from alleged torture of detainees held at Guantánamo and elsewhere in connection with armed conflict. ${ }^{215}$

Article 15 of the CAT requires that state parties "shall ensure that any statement which is established to have been made as a result of torture shall not

CAT Transmittal] (noting that "Article 16 is arguably broader than existing U.S. law," and thus recommending a reservation to Article 16 in order "[t]o make clear that the United States construes the phrase [CIDT] to be coextensive with its constitutional guarantees against cruel, unusual, and inhumane treatment").

210. Press Release, U.S. Dep't of State, United States Written Response to Questions Asked by the Committee Against Torture (Apr. 28, 2006), www.state.gov/j/drl/rls/68554.htm [hereinafter CAT Written Response]; CAT Oral Response, supra note 175.

211. Rep. of the Working Group on a Draft Convention Against Torture and Other Cruel, Inhuman or Degrading Treatment or Punishment, Comm'n on Human Rights, 40th Sess. I 5, U.N. Doc. E/CN.4/1984/72 (Mar. 9, 1984). Why a duplicative ban would undermine the prohibition was not clarified.

212. See supra note 210 .

213. See infra note 237 and accompanying text.

214. CAT Oral Response, supra note 175. Because this statement rested on a lex specialis argument, it did not necessarily address whether Guantánamo was properly considered "territory under [U.S.] jurisdiction" for the purposes of relevant CAT articles. See CAT, supra note 148, arts. 2, 5, 7, 11 $13,16$.

215. A scant handful of courts had previously addressed U.S. obligations under Article 15 in the extradition context. See, e.g., In re Extradition of Atuar, 300 F. Supp. 2d 418, 432 (S.D. W. Va. 2003) aff'd sub nom. Atuar v. United States, 156 F. App'x 555 (4th Cir. 2005) (holding that even if the CAT were self-executing, petitioner had not "established" that the relevant statement was made as a result of torture). 
be invoked as evidence in any proceedings, except against a person accused of torture as evidence that the statement was made."216 During the advice and consent to ratification process, the Reagan Administration clarified to the Senate that existing U.S. law provided more protective exclusionary rules than the CAT provision, based on both U.S. constitutional protections as well as evidentiary hearsay rules. ${ }^{217}$ Therefore no further implementing legislation was created or considered necessary in order to effectuate U.S. compliance with Article 15.

Thus when questions arose regarding the application of Article 15 to proceedings at Guantánamo, officials suddenly faced the need to crystallize U.S. views on the provision. On the one hand, several U.S. government officials had repeatedly stated, including within the context of the CAT committee hearings, U.S. views on the non-applicability of the CAT to detention operations. ${ }^{218}$ On the other hand, the plain language of Article 15"in any proceedings"-would not seem to permit any exception. When the U.S. government submitted its report in the spring of 2005, it dodged this question by restricting its response to U.S. criminal laws applicable domestically. While it discussed various proceedings in use at Guantánamo-specifically, Combatant Status Review Tribunals (CSRTs), Administrative Review Boards (ARBs), and military commissions - it made no mention at all of evidentiary standards for coerced statements or of the applicability of any CAT provisions to these proceedings. ${ }^{219}$ Considering the U.S. position on the limited scope of the CAT in armed conflict, and, in particular, to detainee operations, the Committee might have reasonably assumed the U.S. position was that Article 15 simply did not apply to these proceedings. The Committee thus asked explicitly, in its questions following the U.S. submission, how the U.S. government implemented the Article 15 prohibition in CSRTs and ARBs at Guantánamo. ${ }^{220}$ And the U.S. delegation answered, in a response that may have shocked some of the Committee members and other followers of the matter: "Article 15 of the Convention is a treaty obligation of the United States, and the United States is obligated to abide by that obligation in Combatant Status Review Tribunals and Administrative Review Boards."221

The U.S. response also included a reference to a recent update in its military commissions proceedings, asking that the Committee take note of the recently issued "Military Commission Instruction Number 10, dated March 24, 2006, which provides that 'the commission shall not admit statements established to have been made as a result of torture as evidence against an

216. See CAT, supra note 148.

217. CAT Transmittal, supra note 209, at 14-15.

218. See supra notes 210-214 and accompanying text.

219. Convention Against Torture and Other Cruel, Inhuman or Degrading Treatment or Punishment, Consideration of Reports Submtted by State Parties Under Article 19 of the Convention: Second Periodic Report of the United States of America to the Committee Against Torture, U.N. Doc. CAT/C/48/Add.3 (June 29, 2005) [hereinafter Second CAT Report].

220. CAT Written Response, supra note 210, ๆ 42.

221. Id. 
accused, except as evidence against a person accused of torture as evidence the statement was made.",222 That Commission Instruction, issued by the Department of Defense General Counsel Jim Haynes just over a month before the delegation made its way to Geneva, and well after the U.S, team had received the specific questions from the Committee requesting a direct response on the CAT's applicability to Guantánamo proceedings, itself references CAT Article 15 when presenting the new rule, though an explicit statement of the CAT's applicability to military commissions is absent both in the Instruction and in the response to the Committee. ${ }^{23}$

What led to the seemingly sudden decision by the U.S. government to bind itself explicitly to legal constraints under the CAT that it had previously seemed to evade? Who was responsible for this legal interpretation and what was the influence of the CAT reporting process on the internal decision process? It is impossible to determine one single factor that led to the statement before the CAT Committee and the prior changes to the military commission rules, but it is likely that the existence and looming deadline of the reporting process played an influential role in both; that the decisionmaking procedures, relevant players and their relative influence were shaped by the nature of the process; and that the ultimate legal position might very well have been avoided or come out a completely different way had the matter first arisen in a different context.

First, the position taken by U.S. government officials at the CAT Committee on Article 15 was no mistake. To the contrary, it is clear from what is known about this statement and the reporting process, and from the description in the report itself, that statements made to the Committee were the thoroughly considered product of multiple agencies and officials at many levels working assiduously over the course of several years and through extensive coordination. ${ }^{224}$ Although the reporting process was led by the State Department, the reports and follow-up questions were vetted thoroughly through relevant agencies. ${ }^{225}$ The answers were prepared in advance in written form by an interagency process, and then delivered orally by a delegation consisting of high-level representatives from the Departments of State, Defense, and Justice. ${ }^{226}$

Second, as a structural matter, in contrast to the litigation context, $\mathrm{L}$ attorneys held the pen on drafting the treaty report and subsequent questions,

222. Id.

223. William J. Haynes II, Military Commission Instruction, U.S. DEP'T OF DEF. 10 (Mar. 24, 2006), http://www.defense.gov/news/Mar2006/d20060327MCl10.pdf.

224. See, e.g., Second CAT Report, supra note 219, if 2 (explaining that the "report was prepared by the U.S. Department of State ... with extensive assistance from the U.S. Department of Justice . . . the U.S. Department of Homeland Security . . the U.S. Department of Defense . . . and other relevant departments and agencies of the United States Government").

225. Id.

226. CAT Written Response, supra note 210; CAT Oral Response, supra note 175 (statements of State Department Legal Adviser John Bellinger, Department of Defense Deputy Assistant Secretary of Defense for Detainee Affairs Cully Stimson, and Department of Justice Associate Deputy Attomey General Tom Monheim). 
and the State Department Legal Adviser was the head of the delegation to the Committee in Geneva when the government presented its responses. ${ }^{227}$ This does not mean that $\mathrm{L}$ attorneys held ultimate authority over legal interpretation in preparing the report, or over this question specifically. To the contrary, there is no question that attorneys in the Department of Defense, in particular, and Justice as well, were involved in crafting the answers. ${ }^{228}$ DOD attorneys may very well have penned this response. And DOJ attorneys would certainly have cleared on it, though it would most likely have been OLC rather than the litigating offices; certainly, if they were involved at all, litigators would not have had ultimate decisionmaking authority. ${ }^{229}$ Instead, the balance of power would have shifted-at least as a relative matter-in the direction of State Department officials as coordinators of the process, and Defense Department officials as the relevant clients who would have to comply with any eventual decision.

Third, as noted above, U.S. officials view the reports and subsequent meetings with the Committee as opportunities to highlight positive aspects of U.S. policies and compliance with the treaty. Moreover, this particular round of treaty reporting took place in an incredibly tense, even hostile, time for U.S. relations with the international community on these issues. The fact that the State Department organized such a high-level delegation, which included officials from DOD and DOJ, suggests that U.S. officials were doing everything they could to show respect for the Committee, and may have hoped to use the opportunity to promote a better image and better relationships internationally. ${ }^{230}$ If any context could prompt forward-leaning positions from U.S. government officials, this was one.

I do not argue that the CAT Committee reporting process was the only factor in the government's legal interpretation of its Article 15 obligations, though it provided the forum in which to do it. In fact, there were many domestic issues percolating at the time of this process that bore directly on some of these questions. The Bush Administration had faced extended criticism for some time regarding what critics viewed as overly lax and unjust standards in the various proceedings addressing detention and punishment at Guantánamo Bay. It was in the midst of incremental reforms in the face of sharp public outcry, adverse Supreme Court decisions, and congressional legislation seeking to modify Guantánamo procedures. ${ }^{231}$ In particular, Congress had in 2005 passed the Detainee Treatment Act (DTA), which, in pertinent part, required that CSRTs and ARBs take into account, when assessing the "status or disposition of any detainee," "whether any statement derived from or relating to

227. CAT Oral Response, supra note 175.

228. See supra note 224.

229. Id.

230. See supra note 226.

231. See, e.g., Detainee Treatment Act of 2005, Pub. L. No. 109-148, div. A, tit. X, 119 Stat. 2739 (2005) (codified as amended at 42 U.S.C. $\$ \S 2000$ dd to $2000 \mathrm{dd}-1$ (2006)); Rasul v. Bush, 542 U.S. 466 (2004). 
such detainee was obtained as a result of coercion; and ... the probative value (if any) of any such statement.,"232

The 2005 DTA requirement that administrative judges assess the probative value of coerced evidence was certainly a far cry from a total ban on statements derived from torture, but it nevertheless had the potential to bring matters of detainee abuse into the open and squarely before the Guantánamo tribunals. ${ }^{233}$ In any event, by the time the DTA was enacted, DOD had already conducted the vast majority of CSRTs and had only a few remaining. ${ }^{234}$ As a matter of practice, decisions were made to avoid relying on evidence that related to allegations of abuse. Thus, DOD was able to stave off potential legal interpretations by the administrative boards regarding the government's evidentiary obligations under the CAT, and certainly did not itself make any pronouncement of those obligations. ${ }^{235}$ Nevertheless, these reforms did make it more feasible for DOD subsequently to bind itself to a clear statement on Article 15, which would have been much more difficult were DOD simultaneously planning to rely on such evidence as a matter of practice.

Regardless of what precise factors led to the government's ultimate statement to the CAT committee, it is difficult to imagine that had this exact issue instead first arisen in litigation at that time, government briefs would have included a categorical statement that Article 15 functioned as an exclusionary rule applicable at Guantánamo. The scant briefs that had addressed Article 15 claims in the past had generally considered these claims as subsumed within constitutional considerations, or had refused to accept that international law would require suppression of statements. ${ }^{236}$ And in contemporary cases involving claims of CAT violations, such as Rasul, the responding DOJ briefs did not directly address - and certainly did not concede-those claims. ${ }^{237}$ Instead, the relevant U.S. litigation positions focused on the argument that

232. Detainee Treatment Act of 2005, Pub. L. No. 109-148, div. A, tit. X, $\S 1005(\mathrm{~b})(1), 119$ Stat. $2739,2741(2005)$ (codified as amended at 42 U.S.C. $\$ \S 2000$ dd to 2000 dd-1 (2006)).

233. Id.

234. Those remaining eventually included Khalid Sheik Mohammed and other High Value Detainees transferred to Guantánamo from CIA prisons in 2006. See, e.g., Gerry J. Gilmore, High-Value Detainees Moved to Gitmo; Bush Proposes Detainee Legislation, AM. FORCES PRESS SERVICE (Sept. 6, 2006), http://www.defense.gov/news/newsarticle.aspx?id=721.

235. What relevance, if any, this determination or the govemment's subsequent statement to the CAT Committee had to prior completed processes is unclear. Certainly DOD did not provide new CSRTs or ARBs to all of the detainees who had gone through the process previously, who presumably did not benefit from this understanding of Article 15, and the DTA specifically exempted prior proceedings from this clause's reach. See Detainee Treatment Act of 2005, $\$ 1005$ (b)(2) (2006).

236. See, e.g., Reply to Government's Response to Muhammad Salah's Motion To Suppress, United States v. Marzook, 383 F. Supp. 2d 1056 (N.D. Ill. 2005) (No. 03 CR 978), 2005 WL 5818368, at *21 (arguing first that the international law inquiry regarding whether the statements are derived from torture is subsumed by the constitutional requirement that the statements be voluntary, and second that "suppression is not an appropriate remedy for a violation of international law").

237. See, e.g., Individual Defendants' Motion To Dismiss, Rasul v. Rumsfeld, 414 F. Supp. 2d 26 (D.D.C. 2006) (No. 04-1864), 2005 WL 6003479 at *18, ${ }^{*} 24$ (arguing simply that "the Constitution does not apply extraterritorially to protect non-resident aliens from U.S. military operations outside the country" and that defendants "lacked sufficient connections to this Nation to be afforded constitutional protections even if they had been held on territory within the United States"). 
detainees at Guantánamo did not have constitutional rights. ${ }^{238}$ Considering that the U.S. position to the Senate had been that the U.S. could effectuate its Article 15 obligations through already existing constitutional rights, it is unlikely that the litigators challenging in court the applicability of constitutional rights to Guantánamo would have been keen to concede similar rights stemming from a different source. ${ }^{239}$ It is likely that instead the litigation position would have highlighted prior U.S. statements about the non-selfexecuting nature of the treaty provision, and might have avoided the merits question altogether. ${ }^{240}$ Had U.S. officials then found themselves before the CAT committee once the matter had already been the subject of litigation, they might have found themselves constrained by former statements made in briefs or they might have simply evaded the question by deferring to pending litigation.

All of this raises the quite reasonable question: so what? After all, it is possible and likely that the U.S. government's position at the time on what evidence was actually "established to have been made as a result of torture" did not correspond perfectly with that of the committee. ${ }^{241}$ It is even possible that differing understandings of exactly what this prohibition entailed were part of what permitted interagency agreement on making the statement to the CAT committee at all. Nevertheless, going forward, the executive and Congress have built on rather than narrowed the approach taken at the CAT committee. ${ }^{242}$ Even throughout the Bush Administration there were multiple instances when military commission judges deemed inadmissible evidence they determined tainted by torture. ${ }^{243}$

Moreover, the exact question of the U.S. government's obligations under Article 15 in Guantánamo cases did ultimately arise in domestic litigation. In 2009 , in the context of a Guantánamo habeas case, Judge Kessler asked the parties to submit briefing on federal and international law concerning the admissibility of evidence procured by torture. ${ }^{244}$ DOJ litigators and other officials, with the assistance of lawyers throughout the interagency, scrambled to formulate a U.S. position on the matter. Whatever the range of potential interpretations on the table, it was surely difficult to disregard the fact that the

238. Id.

239. See supra Subsection III.A.6.

240. See supra note 215.

241. See, e.g., Greg Miller, Waterboarding Is Still an Option, L.A. TIMES, Feb. 7, 2008, http://articles.latimes.com/2008/feb/07/nation/na-torture7 (emphasis added).

242. See, e.g., Military Commissions Act of 2006, 10 U.S.C. $\S 9488$ (2006); Military Commissions Act of 2009, 10 U.S.C. $\$ 948$ r (2006). Moreover, the applicability of Article 15 to detainees at Guantánamo raises broader questions concerning the lex specialis approach and extraterritorial application of human rights treaties. See, e.g., Exec. Order No. 13,491, 3 C.F.R. 13491 (2009) (citing the CAT among the laws applicable to individuals detained in armed conflict).

243. See, e.g., Ruling on Defense Motion To Suppress Out-of-Court Statements of the Accused to Afghan Authorities (D-022), United States v. Jawad, 1 M.C. 345 (Military Comm'n Guantánamo Bay, Cuba Oct. 28, 2008), available at http://www.defense.gov/news/d20081104JawadD022Suppress.pdf.

244. Respondents' Brief in Response to the Court's Order of Sept. 4, 2009 at 1-2, Mohammed v. Obama, 704 F. Supp. 2d 1 (D.D.C. 2009) (No. 248). 
U.S. government had taken a firm stance on the applicability of Article 15 to Guantánamo back in 2006. If the Bush Administration could acknowledge the applicability of CAT Article 15 to the now discredited CSRT proceedings on Guantánamo, how could the Obama Administration deny its applicability in habeas proceedings in U.S. federal courts? Ultimately, DOJ filed a brief in response to Judge Kessler's request, stating that "[c]onsistent with ... the treaty obligations imposed by the Convention [Against Torture] on the United States as a State Party, the government does not and will not rely upon statements it concludes were procured through torture in the Guantanamo habeas litigation." 245 This position was no mere talking point. The U.S. government reviewed and in many cases withdrew numerous pieces of evidence that had been filed in the Guantánamo habeas cases in prior years. ${ }^{246}$ And in a 2011 executive order providing for periodic review of continued detention at Guantánamo, established as a discretionary measure rather than an attempt to supplant mandatory habeas, and thus more akin to the obsolete ARBs, President Obama mandated that such review "be implemented ... consistent with applicable law including ... the Convention Against Torture...."247 The resulting guidelines clarified that the review boards "shall not rely on information obtained as a result of torture or cruel, inhuman, or degrading treatment." 248

It is impossible to know the relative influence of one particular factor on years of incremental decisionmaking. Nor is it possible to know whether the Obama Administration would have issued such categorical statements regarding the applicability of Article 15 to various procedures at Guantánamo regardless of the Bush Administration's statements to the CAT Committee. It is worth reiterating that despite the assumed views of the new Administration, many other positions taken in litigation in this area nevertheless remained consistent after President Obama took office. ${ }^{249}$ Thus, it is certainly easy to imagine that the prior statement regarding the applicability of the Article 15 rule to Guantánamo would have hindered the possibility of taking a different

245. Id.

246. See Obaydullah v. Obama, 688 F.3d 784, 796 (D.C. Cir. 2012) (stating that petitioner's "allegations of abuse led the government to withdraw reliance on [particular] statements he made"); Charlie Savage, Appeals Court Sides with Detainee, N.Y. TIMES, July 4, 2010, at A15 (noting that the government withdrew evidence). This fact alone suggests at a minimum that officials within the Obama and Bush Administrations likely had different views on the scope of the Article 15 obligation, as they made different decisions with respect to reliance on evidence. There was also a disparity in information, as many new allegations of taint came to light during the progress of habeas litigation.

247. Exec. Order No. 13,567, 76 Fed. Reg. 13,227, § 10(b) (Mar. 7, 2011).

248. Deputy Sec'y of Def., Implementing Guidelines for Periodic Review of Detainees Held at Guantanamo Bay per Executive Order 13567, DEPARTMENT OF DEFENSE (Oct. 31, 2012), http:/www.dtic.mil/whs/directives/corres/pdf/DTM-12-005.pdf.

249. See, e.g., supra notes 120,130-131 and accompanying text; see also March 13 Brief supra note 77 (making some changes to the govemment's position on its legal authority to detain at Guantanamo, but nonetheless continuing to assert broad authority to militarily detain members and supporters of al Qaeda and Taliban forces, based on an expansive concept of membership in those groups). 
position in 2009 , and could have, in addition, provided a certain degree of political cover that made it easier to apply that provision going forward.

Ultimately, it is unlikely that any one aspect of this protracted decisionmaking process was the deciding factor in the evolution of the executive's legal views. Multiple features of this process came together in a perfect storm of sorts to enable the U.S. government to take a suddenly forward-leaning interpretation of its legal obligations. As Part III described and this case study illustrated, however, the unique nature of the particular interpretation catalysts at work can have a transformative effect on every step of the process, from the first responders who determine how the executive will engage with an issue, to the ultimate decisionmaking players, as well as on the pressures and interests at stake in a given decision. While the extent to which a resulting substantive decision turns on these factors will be case-specific and impossible to prove concretely, the significance of interpretation catalysts in shaping these decisions is undeniable.

\section{IMPLICATIONS OF THE INTERPRETATION CATALYST PHENOMENON}

Executive decisions are almost always over-determined, and thus it would be foolish to try to point to one particular factor and argue that it is the sole reason for a chain of events taking place and the eventual output. Interpretation catalysts are factors that influence processes; it is unlikely and certainly impossible to prove that they are the sole deciding factors in any given decision. But, as explored in the preceding sections, they do exert an undeniable influence. There are a number of implications that can be drawn from this description of executive dynamics in legal decisionmaking.

\section{A. Implications for Scholarship}

The description of interpretation catalysts advanced in this Article has implications for a number of ongoing debates in current scholarship, in particular, deliberation over the ideal placement of authority within the executive; why the executive arrives at particular understandings of its legal constraints; and the extent to which the positions taken by one presidential administration may bind the next, including the extent to which the President is constrained by law at all. ${ }^{250}$

Considerations of institutional design and the ideal placement of decisionmaking authority within the executive, for example, are intimately connected to-and can be subverted or facilitated by-the role played by interpretation catalysts in informing these structures. This is illustrated by the examples in Part II of decisionmaking formally directed into particular fora, such as NSC committees or interagency task forces, but rechanneled by events or lawsuits into other decisionmaking processes. ${ }^{251}$ Thus, in contrast to the

250. See supra notes $7,12-15,37-38$.

251. See supra Subsection II.B.2. 
description of scholars like Elena Kagan and Bruce Ackerman who, respectively, endorse or warn against a powerful President commanding an increasingly politicized executive branch, ${ }^{252}$ presidential prerogatives are often thwarted by the interaction of internal and external factors with a massive, dynamic executive bureaucracy. Potential constraints on presidential decisionmaking include not only the structural constraints that are the focus of much scholarship, such as Congress or, internally, OLC; they also include the nature of the events themselves that drive that decisionmaking, and the interplay between those events and the organic reality of internal executive process.

Interpretation catalysts also have significance for those seeking to divine reasons for particular positions taken by the executive. Much debate currently centers on whether and why the Obama Administration has chosen to adopt certain policies and legal interpretations of the prior Administration in the national security context. Scholars have pointed to rational, structural, and political reasons for this phenomenon. Some have argued, for example, that once in office Obama came to accept that "the threat is real" and that the Bush policies were "better-thought-out-than they realized,"253 or have noted structural impediments to change, such as the remarkable continuity of the individual players in the national security bureaucracy across the two Administrations, and the underlying career bureaucracy, which does not turn over with the new Administration. ${ }^{254}$ Still others have pointed to the dramatic change in political climate or political blunders the Administration made after taking office ${ }^{255}$ These discussions do not address the role of interpretation catalysts, yet all of these factors are inextricably connected to the context in which decisions arose for the new Administration, and the processes and players that were triggered to resolve them. A study of the executive's position on the lawful scope of detention authority, for example, would be incomplete without examining the critical role litigation played in driving the Administration to assert legal views formed under the distinct pressures described in Section III.A, rather than through the processes the Administration had intended to employ. ${ }^{256}$

Moreover, interpretation catalysts have implications for longstanding debates surrounding whether and to what extent the executive is bound by law at all. Eric Posner and Adrian Vermeule offer a quite categorical approach to executive power, arguing that the law provides no per se constraint on the executive, nor should it, in times of emergency or otherwise. ${ }^{257}$ Scholars who have reached similar conclusions about the descriptive state of the presidency but are driven by opposing instincts with respect to the ideal, advocate greater

252. See, e.g., ACKERMAN, REPUBLIC, supra note 7; Kagan, supra note 37.

253. GOLDSMITH, POWER AND CONSTRAINT, supra note 6, at 25-26 (quoting Susan Collins).

254. Id. at 27.

255. See, e.g., KLAIDMAN, supra note 77.

256. See supra notes 76-79 and accompanying text.

257. See, e.g., POSNER \& VERMEULE, supra note 8. 
institutional constraints on executive power. ${ }^{258}$ Others have suggested a more nuanced approach to the relationship between the executive and legal constraint, one that takes into account constraints both internal-such as the role of OLC in constraining the President--and external such as Congress and the courts. ${ }^{259}$ The account of interpretation catalysts presented here provides valuable texture to all sides of this debate. Scholars persuaded by either the Posner/Vermeule or Ackerman approach to current executive constraints may see in this phenomenon a certain degree of ad hocery; the reality that different decisionmaking triggers and processes may result in different substantive outcomes certainly suggests a lack of essential truth about the right legal outcome, or at least a lack of consistency in the executive's assessment of legal questions. Yet the interpretation catalysts account also reveals a rich bureaucracy and deep layers of intertwined decisionmaking that suggest the operation of legal and other constraints within the executive are far more complicated than whether and to what extent executive lawyers are willing to tell the President "no," or whether the President listens to those lawyers. A thorough investigation of the limit and extent of Presidential power must take into account how legal questions arise, how the actors who address these questions view legal constraints on executive authority, and the structures and processes in place that allocate power among those actors and shape the resulting decisions.

\section{B. Implications for Advocates}

For those seeking to influence executive behavior, an understanding of the influence of interpretation catalysts is invaluable to an advocacy strategy. Understanding how external factors and decision entry points connect to the various levers and gears within a bureaucracy, and how they can operate to empower and undermine various players, is essential to understanding where one's efforts may be most effective and where they can, in fact, be harmful to one's cause.

The risks of misunderstanding interpretation catalysts can be enormous. For example, conventional wisdom might suggest that litigation is the best means for effecting legal constraints on executive power. Yet a solely litigation-based strategy for effecting change in national security matters can backfire in long-lasting ways. As the preceding sections make clear, it is an understatement to say that any attempt to instigate radical change within the executive in this area through the vehicle of litigation faces a steep uphill

258. See, e.g., ACKERMAN, REPUBLIC, supra note 7.

259. See, e.g., GOLDSMITH, POWER AND CONSTRAINT, supra note 6; Metzger, supra note 7, at 425-26 (arguing that "[i]nternal checks can be, and often are, reinforced by a variety of external forcesincluding not just Congress and the courts, but also state and foreign governments, international bodies, the media, and civil society organizations," and that "the reinforcement can also work in reverse, with internal constraints serving to enhance the ability of external forces ... to exert meaningful checks on the Executive Branch"); Morrison, Alarmism, supra note 7; Pildes, supra note 8. 
battle. $^{260}$ Consider even the strategy of turning to the courts to rein in the executive's use of a war paradigm to address the conflict with al Qaeda in the years after 9/11. The Bush years are often cast as a time of momentous Supreme Court pushback against administration policies in areas where presidents had previously been awarded great deference. That is one narrative, and there is truth in it. Certainly the Court asserted itself on several occasions to keep the courts and Congress from being shut out completely from significant policies affecting the nation and individual rights. Yet despite the handful of rare wins for such advocates-and they are rare $\mathrm{e}^{261}$ - there is another story in this history that is less examined; it is a story of repeated years of litigation that did not radically alter the legal architecture for the Bush Administration's policies in its "War on Terror." Instead, this litigation entrenched it. ${ }^{262}$

Officials in the Obama White House and Justice Department came into office determined to avoid the criticism of over-politicization of DOJ that plagued the last Administration. Yet they faced a status quo of eight years of litigation defending Bush-era practices, to which the inherently defensive nature of litigation was structurally inclined to defer; this in addition to political pressures and the incredibly fast-paced onslaught of litigation came together quite effectively to make it exceedingly difficult for the new Administration to change course and suddenly take new positions in litigation, above all those that might constrain government action or fail to defend past government policies. ${ }^{263}$ While room might technically exist for the Administration to later revisit these positions, once positions are taken in litigation-particularly if they are then accepted by courts-executive officials both feel less pressure to establish a more constraining position, and are unlikely to recommit time and resources to addressing it.

Of course, the U.S. government does not win every case to which it is a party. And a binding decision from a federal court is thus significant potential upside for plaintiffs attempting to effect change in the executive's actions, but

260. In the national security realm, much turns on the likelihood of court intervention, the political and practical consequences of that intervention, and the likelihood of effecting change through another means. Foreign jurisdictions where courts defer less to state action in this area, for example, present a very different calculus.

261. Since Boumediene, the Supreme Court and the D.C. Circuit (which has handled the vast majority of the national security litigation the U.S. government has faced) have not ruled against the government in any major national security case. The Supreme Court has in fact granted certiorari in very few cases and has permitted broad deference by lower courts to executive positions in this area. See, e.g., Kiyemba v. Obama, $131 \mathrm{~S}$. Ct. 1631 (2011) (denying petition for certiorari to determine whether courts could grant release of unlawfully-held Guantánano detainees into the United States); Holder v. Humanitarian Law Project, 130 S. Ct. 2705 (2010).

262. See, e.g., Boumediene v. Bush, 553 U.S. 723 (2008) (permitting ongoing long-term military detention at Guantánamo with few specified review requirements); Hamdan v. Rumsfeld, 548 U.S. 557 (2006) (supporting the application of an armed conflict framework to the conflict with alQaeda); Hamdi v. Rumsfeld, 542 U.S. 507 (2004) (upholding the right of habeas corpus for U.S. citizens detained on U.S. soil, but supporting the armed conflict paradigm and reading the AUMF to permit long-term military detention of such individuals without trial).

263. See supra note 249 . 
the risk is also enormous. If such plaintiffs lose-and it is not unreasonable to assume that they will in the national security context-the position that the executive takes in litigation is likely to be not only upheld but entrenched, giving that position that much more weight going forward. ${ }^{264}$

Aspirations for executive change might include a range of goals: greater transparency, clarity of the executive's position, change in policy or its implementation, or change in the legal position of the executive with respect to its obligations as a matter of law. As discussed above, the priority of these goals should affect the path taken to challenge executive positions. With an especially recalcitrant regime that is unlikely to respond to other more persuasive means of effecting change, or an executive that is bent on what the courts may deem process fouls (as they have viewed certain executive attempts to cut the other branches or particular players out of the decisionmaking process ${ }^{265}$ ), litigation may well be the only way to force the executive's hand. When other potential avenues exist, however, private advocates might seek to employ interpretation catalysts that trigger the processes and elevate the players they believe will be most amenable to the particular outcome they are hoping to effectuate.

\section{Implications for the Courts}

Exploration of how interpretation catalysts can shape - and vary-the legal positions the executive takes on matters of national security and international law should force a rethinking of the current state of judicial deference in this area, on which this Article only skims the surface. Deference in the national security and foreign affairs area exists for many reasons, among them a belief in the superior expertise and political accountability of executive decisionmakers. ${ }^{266}$ Yet the phenomena demonstrated in this Article suggest that the positions the executive presents in litigation are not necessarily the result of such factors, but rather are often exactly what they purport to be: litigation positions. ${ }^{267}$ This should concern many supporters of the current state of deference.

264. See, e.g., Korematsu v. United States, 323 U.S. 214, 245-46 (1944) (Jackson, J., dissenting) (arguing that judicial sanction of an executive action can be far more dangerous than the underlying action itself, by turning a "passing incident" into doctrine).

265. See Neal Katyal, Hamdan v. Rumsfeld: The Legal Academy Goes to Practice, 120 Harv. L. REV. 65, 71 (2006) (arguing that the Court's concern with the executive's position was based on its lack of support both from Congress, and from "the bureaucracy, and in particular the Judge Advocates General and the State Department"); Deborah N. Pearlstein, The Soldier, the State, and the Separation of Powers, 90 TEX. L. REV. 797, 822-23 (2012) (suggesting that the Hamdan Court was likely swayed by accounts "that the Administration had bypassed standard internal decision-making processes" in excluding military lawyers "from the process of developing a commission trial system"). One might even argue that it is in precisely these kinds of cases that the executive is most likely to lose the case in court, suggesting that such circumstances might present the best vehicles for litigation as a catalyst for progressive change. 664 (2000).

266. See, e.g., Curtis Bradley, Chevron Deference and Foreign Affairs, 86 VA. L. REV. 649,

267. See, e.g., Pillard, supra note 61, at 683 (noting that "[t]he SG's and OLC's formal doctrinalism and their courtlike insulation from the day-to-day functioning of government mean that 
Administrative law jurisprudence in fact suggests that with perfect information, judges would not choose to defer to mere litigation positions. ${ }^{268}$ But in order to avoid doing so, they require an understanding of the internal processes used to arrive at the government's position in the case before them; the executive is not likely of its own accord to alert the court that a litigation position conflicted with the considered views of a relevant agency (though there are sometimes clues for close observers) ${ }^{269}$ Yet whichever criterion most interests the court in choosing to defer-be it expertise, accountability, fluency in historical precedent, or role in the formation of foreign policy or international law ${ }^{270}$ - such choice might engage the relative competence of a different component of the executive branch. Thus, in order to defer to a particular executive capability, the courts need to understand which component's view they are assessing.

One way courts might target their deference more precisely at specific executive capabilities is to condition specialized deference based on the engagement of specific actors or processes. While this may sound aggressive, it is not entirely novel. Kagan and Barron argue in Chevron's Nondelegation Doctrine that courts should differentiate among internal agency actors when assessing the standard of review to afford an agency's decision, and should award Chevron deference only when a particular decision "bears the name of the statutory delegate" following "a meaningful review of the interpretation by the delegatee or her close advisors."271 In fact, whether and how courts choose to examine the underlying process behind the government's litigation position can influence how the government designs and follows that process. Magill and Vermeule have argued that administrative law jurisprudence-in particular, rules granting more or less deference to agency lawmaking-operates to elevate or weaken the influence of different officials within agencies. ${ }^{272}$ Kagan and Barron have taken this concept a step further to argue that courts should incentivize particular executive decisionmaking by rewarding those processes

they lack the insight into executive practical experience and varied institutional capabilities or limitations that distinguish the executive from the courts").

268. Barron \& Kagan, supra note 28 , at 260.

269. See, e.g., Margaret H. Lemos, The Solicitor General as Mediator Between Court and Agency, 2009 MiCH. ST. L. REV. 185, 197 (2009) (noting that "it can be extraordinarily difficult to determine whether the arguments presented in the SG's briefs represent the views of the relevant agency"). But see infra note 275 (noting the role of agencies' signatures on Solicitor General briefs as evidence of agreement in some cases).

270. See Ingrid Weurth, The Alien Tort Statute and Federal Common Law: A New Approach, 85 NOTRE DAME L. REV. 1931 (2010) (arguing that the executive branch should receive deference where it "can demonstrate a strong interest in (or prior position with respect to) the formation of a particular norm of customary international law").

271. Barron \& Kagan, supra note 28, at 201-02, 239.

272. Magill \& Vermeule, supra note 37 , at 1079-80 (arguing that greater judicial review empowers lawyers within agencies, and that when "there is little threat of judicial review, ... lawyers lose their place at the table as the agency debates and deliberates over the action"). I do not necessarily agree that the lack of judicial review entails a lack of attorney involvement within the executive, but certainly judicial interaction with the executive has a strong influence on the relative importance of specific attomeys within agencies, and litigators in particular. 
that result in decisionmaking at a higher level. ${ }^{273}$ Thus, judges wishing to incentivize greater influence for particular types of actors within the government-be they officials who have more expertise, are more accountable, or are more independent (each of which may pull in different directions) - can do so simply by conditioning their deference on whether such actors are involved.

Courts could choose more formally to engage the practice of seeking clarity on executive decisionmaking as a condition of deference, whether or not they wish to incentivize particular kinds of decisionmaking. Deference-shifting would be a much softer approach than a requirement of transparency into internal executive deliberation, which would raise a host of separation-ofpowers concerns. Instead, decisions regarding whether and how to change internal procedures and how much information to provide to the court would be left to the executive, which could always choose to rely on a merits-based argument rather than a request for judicial deference. Such a deference-shifting approach would simply condition deference to expertise or accountability on executive willingness to demonstrate that those internal components with specific competencies were sufficiently involved or had cleared on the position. ${ }^{274}$ U.S. government officials already employ a kind of signaling in certain circumstances, to subtly alert the court that agency officials are on board with a position, through the practice of agency officials' signing of briefs that are particularly relevant to an agency's interests; similarly, the unusual absence of a signature can signal that official's displeasure with the product. ${ }^{275}$ This practice could take on a more formal status with the courts.

There is some evidence in the national security arena that courts are interested in peering behind the executive curtain to some extent. In some cases, judges have questioned or given less deference to statements made by DOJ officials when they viewed such statements as either not sufficiently

273. Barron \& Kagan, supra note 28, at 201-02, 204, 239 (arguing that courts should "reward, through more deferential judicial review, interpretations offered by more responsible officials," thus "offering an incentive to certain actors to take responsibility for interpretive choice, [so as to] advance[] both accountability and discipline in decision making").

274. See, e.g., Jody Freeman \& Jim Rossi, Agency Coordination in Shared Regulatory Space, 125 HARV. L. REV. 1131 (2012) (arguing that courts may attach greater deference to decisions arrived at through greater interagency coordination); Derek Jinks \& Neal K. Katyal, Disregarding Foreign Relations Law, 116 YALE L.J. 1230, 1280 (2007) (arguing that the executive should not receive judicial deference in the foreign affairs realm when it bypasses "existing channels and procedures" and "interagency debate," and disregards agency expertise).

275. See, e.g., Lemos, supra note 269, at 200 ("treat[ing] an agency's signature on the SG's brief as evidence of agreement, and an agency's failure to join the brief as evidence of disagreement," though acknowledging that "an agency's decision to join the SG's brief is at best a rough proxy for agreement with the arguments presented there"); Savage, supra note 122 (stating that the chief prosecutor of the military commissions system "pointedly did not sign" the appellate brief in a case he had urged the Justice Department to drop.); John Bellinger, Kiobel: Obama Administration Supports Shell, Argues ATS Should Not Apply to Aiding-and-Abetting Suits Against Foreign Corporations, Leaves Open Possibility of Suits Against U.S. Corporations, LAWFARE, (June 13, 2012, 7:55 PM), http://www.lawfareblog.com/2012/06/kiobel-obama-administration-supports-shell-argues-ats-should-not -apply-to-aiding-and-abetting-suits-against-foreign-corporations-leaves-open-possibility-of-suits-against -u-s-corporations (highlighting the State Department's absence on the brief's signature page, despite its regular inclusion in ATS briefs). 
coordinated with particular individuals, or as mere litigation positions, contrary to views of "experts." 276 Yet in others, judges have explicitly disregarded agency views made outside litigation as not representing the considered views of the executive branch as a whole. ${ }^{277}$ The discussion of decisionmaking processes advanced here, however, suggests that there is little reason for courts to view the positions of the attorneys before them in litigation as the products of necessarily greater input or coordination than the positions put forward in executive reports, speeches, testimony, or other statements by executive officials.

\section{Implications for Executive Branch Actors}

Last, executive branch officials, including the President, must understand the nature and influence of interpretation catalysts in order to operate effectively and accomplish their goals within the government. This is particularly critical for new administrations that come into power with specific policies they intend to influence or implement. Interpretation catalysts can provide useful windows for effecting change. But they can also thwart intended structures by diverting a process from a formally-established channel into another, such as an organic process that has historically been triggered by a particular catalyst.

For those inclined to change institutional design so as to maximize presidential or political control over decisionmaking, the phenomena discussed in this Article suggest two potential lessons. First, this requires maintaining decisionmaking processes within the structures the President or others intend for those purposes, such as the formal task forces and other processes established by executive orders. As has been discussed, these processes can be diverted into other channels by the press of real events; maintaining the intended channels requires devoting sufficient resources and authority to the individuals intended to manage such processes, including the ability to overrule or intercede in decisions made in other fora.

Second, to the extent restricting decisionmaking to particular channels is not always possible (and this Article suggests that it is not), those seeking to prioritize certain processes can do so by apportioning weight or precedential value to decisions, even legal interpretations, according to the particular method used and participants involved in reaching them. ${ }^{278}$ Thus, for example,

276. See, e.g., Katyal, supra 265; Pearlstein supra note 265.

277. For example, in the district court opinion in Rasulv. Rumsfeld, the court dismisses what it terms a "State Department report," thus suggesting its view that the U.S. Government lacks a unified position or that the State Department did not necessarily represent it. Rasul v. Rumsfeld, 414 F. Supp. 2d 26, 32 n.5 (D.D.C. 2006). Contrast this with Justice Stevens' reliance on a law review article by thenLegal Adviser Taft as evidence of the Executive's position on law-of-war rules applicable to al Qaeda. Hamdan v. Rumsfeld, 548 U.S. 557, 633 (Stevens, J., concurring).

278. There is no clear manual on how the executive weighs statements made in particular processes beyond OLC precedent, but it is certainly a non-trivial event to part ways with prior stated legal positions. The discussion in Section III.A additionally suggests that there is great pressure to 
positions established by interagency consensus through long deliberation and intensive coordination-such as those taken in particular treaty reports or speeches-would take precedence over those taken under time pressure and with limited coordination-such as those taken in short-fuse litigation decisions. There is little reason to believe, considering the externally-created time pressure and framing of the questions at stake, that urgent litigation deadlines create the ideal circumstances for arriving at the considered views of the executive, particularly when the President has established other processes. Therefore, one lesson to internal actors and the President may be to redesign structures and assumptions so as to preempt litigation-driven decisions to the extent possible by anticipating questions likely to be raised and addressing them in alternate fora and, when preemption is impractical, to permit space ex post for formalized reconsideration of decisions made under exigent circumstances, significant time pressure, or otherwise without sufficient consensus among critical parties. ${ }^{279}$ Moreover, differences between interpretation catalysts might be unavoidable, but they need not be quite so stark. Greater emphasis could be placed on collaboration between agencies; for example, authority over litigation positions might be shared with the client agencies whose interests are at stake.

For those who must work within existing structures, the most effective operators within the executive use interpretation catalysts and related procedural factors to their advantage. ${ }^{280}$ Interpretation catalysts can create opportunities in addition to hurdles. Those whose roles are elevated by certain processes may angle to keep decisionmaking within the processes that grant them or their agency the greatest control over the ultimate decision. Individuals who are left out of the loop may seek ways to gain a seat at the table, such as by seeking to present a speech on a matter, and thus give themselves the pen in crafting a particular presentation of the government's position. They may try to engage internal or external factors to move a matter into a process in which they have greater authority, such as by taking advantage of treaty body reporting processes or working with a congressional committee to bring matters to the fore within a particular process that will emphasize their participation. ${ }^{281}$

Process and structure matter a great deal but these factors alone-and the catalysts triggering them-cannot entirely explain or justify executive decisionmaking. In fact, responsible officials should make all efforts to rise above these challenges in order to promote and establish their best view of the law and the correct course of action and policies. In order to do so, however, it

adhere to prior positions taken in litigation and that any change is considered dramatic. See, e.g., supra note 141 .

279. Reconsideration has its limits. When decisions are made in the course of litigation, reconsideration will inevitably need to factor in the resulting judicial decision and the risk of upending settled cases.

280. See supra Section III.C.

281. See Metzger, supra note 7 (discussing the interdependence of internal and external constraints). 
is essential to understand the procedural and structural phenomena that inherently influence - and can hinder-effective decisionmaking.

\section{CONCLUSION}

Contrary to conventional views of executive lawyering, which posit a difficult but bilateral tension between law and principles, on the one hand, and the President's wishes and policies on the other, the legal architecture of the U.S. executive is in fact a complex, dynamic, and multifaceted community of players and decision mechanisms that engage or retreat according to the unique task at hand and the forum in which it arises. How a question is first raised and framed affects the processes employed to address it, the nature of the players at the table, their authority, and the contextual pressures that shape the enterprise. Interpretation catalysts, which trigger and frame these questions, thus play a dramatic role within the executive in forcing a decision to the fore and shaping every step of the process toward the ultimate substantive result.

The significant role of interpretation catalysts in executive branch legal decisionmaking may provoke different reactions depending on one's view of a commanding Oval Office or a centralized executive legal process. The reality of executive legal decisionmaking described in this Article is neither one of perfect unitary cohesion nor is it completely ad hoc. Rather, the picture is richly textured and provides fodder for theorists on all sides of debates about executive power. For those seeking greater political control over executive legal process, the picture this Article presents should be a call to arms to implement greater top-down order on decisionmaking channels, and to assign weight to legal decisions according to the particular process taken. For those seeking greater internal constraints on executive action, this Article demonstrates not only that these constraints do exist, but that external actors and events can and do influence the internal balance of power. 
